Idaho National Engineering and Environmental Laboratory

Revision 0

INEELEXT-98-00609

WORKBOOK FOR PRIORITIZING PETROLEUM INDUSTRY EXPLORATION AND PRODUCTION SITES FOR REMEDIATION

August 3, 1998

$$
\begin{aligned}
& \text { RECEIVED } \\
& \text { SEP } 151998 \\
& \text { OSTI }
\end{aligned}
$$

G. J. White

Environmental Assessment Technologies

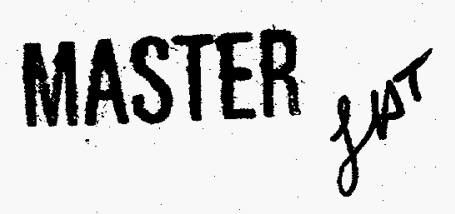

DETREUTION OF THIS DOCUMEN is LULMTER

LOCKHEED MATTIN 


\section{DISCLAIMER}

This report was prepared as an account of work sponsored by an agency of the United States Government. Nelther the United States Government nor any agency thereof, nor any of their employees, makes any warranty, expresil or implied, or assumes any legal liability or responsibility for the accuracy, completeness, or usefullness of any information, apparatus, product or process disclosed, or represents that its use would not infringe privately owned rights. Refereaces herein to any specific commercial product, process, or service by trade name, trademark, manufacturer, or otherwive, does not necessarily constitutie or imply its endorement, recommendation, or favoring by the United States Government or any afjency thereof. The views and opinions of authors expreseed herein do not neceasarily atate or reflect those of the United States Government or any agency thereof. 


\section{DISCLAIMER}

Portions of this document may be illegible in electronic image products. Images are produced from the best available original document. 


\title{
WORKBOOK FOR PRIORITIZING PETROLEUM INDUSTRY EXPLORATION AND PRODUCTION SITES \\ FOR REMEDIATION
}

August 3, 1998

\author{
G. J. White \\ Environmental Assessment Technologies \\ Lockheed Martin Idaho Technologies Company, Inc. \\ Idaho National Engineering and Environmental Laboratory \\ P.O. Box 1625 \\ Idaho Falls, ID 83415-2213
}




\section{CONTENTS}

Executive Summary $\ldots \ldots \ldots \ldots \ldots \ldots \ldots \ldots \ldots \ldots \ldots \ldots \ldots \ldots$

1.0. Introduction and Background . . . . . . . . . . . . . .

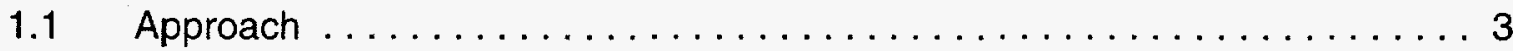

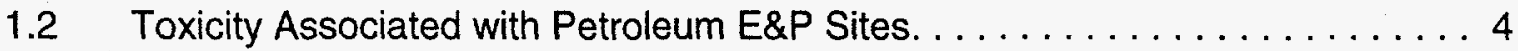

1.3 Physical Disturbance at Petroleum E\&P Sites. . . . . . . . . . . 16

2.0 Workbook for Prioritizing E\&P Sites $\ldots \ldots \ldots \ldots \ldots \ldots \ldots \ldots \ldots \ldots \ldots$

2.1 Facility/Site Description Worksheet $\ldots \ldots \ldots \ldots \ldots \ldots \ldots \ldots \ldots$

2.2 Petroleum Exploration and Production User's Guide . . . . . . . . . . . 20

2.2.1 Petroleum Exploration and Production Site Evaluation Factors . . . . . . 22

2.2.1.1 Evaluation Factors for Contaminant Characteristics . . . . . . 22

2.2.1.2 Evaluation Factors for Contaminant Transport Pathways . . 24

2.2.1.3 Evaluation Factors for Receptors . . . . . . . . . . . . 47

2.2.1.4 Evaluation Factors for Physical Disturbance . . . . . . . .61

2.3 Summary of Scoring Guidelines $\ldots \ldots \ldots \ldots \ldots \ldots \ldots \ldots \ldots$

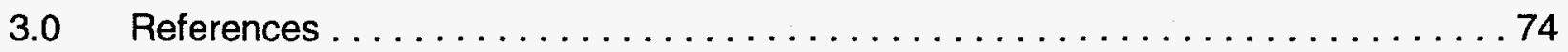

\section{LIST OF TABLES}

Table 1-1. Partial summary of toxic contaminants potentially associated with petroleum exploration and production facilities. . . . . . . . . . . . . . . 10

Table 1-2. Commonly selected indicator compounds for petroleum fuels. . . . . . . . . 14 


\section{EXECUTIVE SUMMARY}

The purpose of this Workbook is to provide a screening-level method for prioritizing petroleum exploration and production sites for remediation that is based on readily available information, but which does not require a full characterization of the sites being evaluated. The process draws heavily from the Canadian "National Classification System for Contaminated Sites", and fits into the framework for ecological risk assessment provided in guidance from the U.S. Environmental Protection Agency. Using this approach, scoring guidelines are provided for a number of "Evaluation Factors" relating to: (1) the contaminants present at the site; (2) the potential exposure pathways for these contaminants; and (3) the potential receptors of those contaminants. The process therefore incorporates a risk-based corrective action (RBCA) framework to estimate the relative threat posed by a site to human health and to ecological systems. Physical (non-toxic) disturbance factors have also been incorporated into the process.

By assigning numerical scores to each Evaluation Factor, sites may be ranked with respect to their relative need for remediation. The approach allows for widely disparate sites to be compared in terms of their relative need for remediation without having to perform a complete characterization and risk assessment. As such, the Workbook represents a screening method that provides scientific and technical assistance in the identification and ranking of sites.

The process described in the Workbook is designed to be flexible according to the needs of the user. Under most circumstances, some of the Evaluation Factors described in the Workbook can be ignored either because the user is only concerned with specific contaminants, pathways, and receptors, or because it is determined that no real differences exist between the different sites being evaluated. Furthermore, the scoring guidelines provided for each Evaluation Factor are just that - guidelines: the user should feel free to alter the relative importance of any Evaluation Factor before applying the method.

It should also be noted that the process described in this Workbook has not yet been field tested at petroleum E\&P sites. The first logical step in the field testing of this process is to apply the method at a small number of sites to assess the availability of the information that is needed to score each evaluation factor. Following this evaluation, the Workbook process should be applied at a series of sites to determine the effectiveness of the process at ranking sites according to their relative need for remediation. Upon completion of these tests, the Workbook should be revised to reflect the findings of the field tests. 


\subsection{INTRODUC'TION AND BACKGROUND}

It is generally recognized within the petroleum industry that potential changes in federal and state environmental regulations relating to the remediation of petroleum exploration and production (E\&P) sites could have considerable impact on future E\&P activities. For the industry to take a proactive stance with respect to the remediation of toxic contaminants and physical disturbance at E\&P sites, a simple screening-level method incorporating a risk-based corrective action (RBCA) framework is needed that will facilitate the estimation of potential threats to human health and to ecological systems resulting from E\&P sites. In short, an easily-applied, consistent process is needed that will allow E\&P sites to be ranked with respect to their relative need for remediation, thereby facilitating the most ccst-effective allocation of funds available for remediation. To effectively accomplish this the process must be applicable to a wide range of E\&P sites, including both active and inactive (retired) sites as well as sites operated by both major oil companies and small companies.

The goal of this Workbook is to provide such a risk-based process for prioritizing petroleum E\&P sites for remediation. The Workbook provides a step-by-step process for evaluating the relative degree of risk to humian health and ecological systems by assigning numerical scores to various aspects of the site relating to the type and degree of contamination or disturbance, potential pathways of contamiriant movement, and potential human and ecological receptors. The sum of the scores for each of these properties provides the total score for an individual site.

The information needed to assign scores to each parameter used to make this assessment should be readily available to those making the determinations. Ultimately, sites are ranked as "high", "medium" or "low" according to their current or potential adverse impact on human health or the environment. This approach therefore allows for widely disparate sites to be compared in terms of their relative need for remediation without having to perform a complete characterization and risk assessment. As such, the Workbook represents a screening method that provides scientific and technicial assistance in the identification and ranking of sites. 


\section{GOAL}

THE GOAL OF THIS WORKBOOK IS TO PROVIDE A USEFUL SCREENING METHOD FOR PRIORITIZING PETROLEUM E\&P SITES FOR REMEDIATION OF ENVIRONMENTAL IMPACTS.

TO MEET THIS GOAL, THE PROCESS MUST:

1. Represent a screening technique for determining the relative need for remediation without relying on a full characterization of candidate sites;

2. Be based on reasonably available information;

3. Be applicable to a wide range of E\&P sites;

4. Be designed to allow for the most cost-effective use of resources available for remediation;

5. Be consistent with EPA guidelines in the application of a risk-based corrective action (RBCA) framework; and

6. Integrate an ecological risk assessment component.

1.1 Approach - Wherever possible, this Workbook has been based on existing methods from a variety of sources, the most important of which is a method for classifying contaminated sites developed by the Canadian government (CCME, 1992). Although the Canadian method provides the basic framework for this Workbook, additional guidance has been adopted from a number of sources. Key among these are (1) Standard Guide for Risk-Based Corrective Action Applied at Fetroleum Release Sites issued by the American Society of Testing and Materials (ASTM, 1995); (2) Proposed Guidelines for Ecological Risk Assessment issued by the Environmental Protection Agency (USEPA, 1996); and (3) the U.S. Fish and Wildlife Service Lands Biomonitoring Operations Manual (Rope and Breckenridge, 1993). All of these methods deal primarily with chemical contaminants. However, the importance of physical disturbance at petroleum E\&P sites is also recognized, and an effort has been made to incorporate physical disturbance into the Workbook. 
1.1.1 National Classification System for Contaminated Sites - As indicated above, the overall approach to this Workbook draws heavily from the Canadian "National Classification System for Contaminated Sites" (NCS), adcpted by the Canadian Council of Ministers of the Environment in 1992 (CCME, 1992). The NCS was developed to provide a defensible method for evaluating contaminated sites according to their "current or potential adverse impact on human health and the environment", recognizing that the physical and chemical characteristics of the site as well as the ultimate risk that they may pose to human health and the environment are extremely variable.

The Canadian NCS process is designed to evaluate the hazard or hazard potential of a site by scoring site characteristics that can be grouped under one of three categories:

1. Characteristics of the contaminant(s) present: This information is needed to adequately define the relative hazard associated with the contaminants present at a site or the relative degree to which physical disturbance has occurred;

2. Exposure pathways: This information describes the route by which a contaminant reaches a receptor. Common exposure pathways include groundwater, surface water, air, or direct contact.

3. Receptors: This information provides adequate descriptions of the organisms, ecological populations, communities, and ecosystems, or the natural resources that are exposed to the contamination.

The NCS process involves the application of an additive numerical method that assigns scores to a number of site characteristics or "Evaluation Factors". Each Evaluation Factor is assigned a score ranging from a low of zero to a high value that is specific to the Evaluation Factor. The most important Evaluation Factors may be assigned factors up to an overall high of 18. The range is designed to weight the Evialuation Factors according to their potential or actual relevance in contributing to the hazard or risk of a site.

One advantage to using the NCS approach to classifying sites is that it the data required to use the Workbook should be generally available. The minimum data requirements for using the Workbook include the following:

- Description of site location;

- Type of contaminants or materials likely to be present at the site (and/or description of historical activities);

- Approximate depth to water table; 
- Geologic map or survey information (soil, overburden, and bedrock);

- Annual rainfall data;

- Surface cover information;

- Proximity to surface water;

- Topographic information;

- Flood potential of site;

- Proximity to drinking water supply;

- Uses of adjacent water resources; and

- Land use information (on-site and surrounding).

Using this system, the NCS enables the user to screen various sites to determine their relative need for further action (e.g. characterization risk assessment, remediation, etc.) to ensure the protection of human health and the environment. Although the NCS process addresses many of the factors involved in a risk assessment study, the procedure should not be used out of context to conduct risk analyses on individual sites. It is therefore intended as a screening method only that may be used to prioritize sites and direct the available funding for remediation in the most cost effective manner.

Although the Canadian NCS process is not oriented specifically toward the petroleum industry, the method can be readily applied to essentially any contaminant situation, and is intended to provide a mechanism for comparing different sites with different hazardous and radioactive contaminants. As with the NCS, the method described in this Workbook is intended to be dynamic in that the process may be revised as new information (e.g. improved risk assessment techniques, changes in regulations governing oil E\&P sites, etc.) becomes available.

As with the NCS, the system described in this Workbook is not designed to provide a quantitative risk assessment, but rather is a tool to screen sites with respect to need for further action (e.g. characterization, risk assessment, remediation etc.) to protect human and animal health and the environment. 


\subsubsection{Standard Guide for Risk-Based Corrective Action Applied at Petroleum}

Release Sites -- Risk-based corrective action (RBCA) is designed to provide "a consistent decision-making process for the assessment and response to petroleum release, based on the protection of human health and the environment" (ASTM, 1995). It involves a set of practical, technically defensible and consistent activities that contribute to the cost-effective management of a site. RBCA advocates the combination of "best available technologies" with "best management practices" in a manner that will ensure the protection of human health and the environment. Several key assumptions are inherent to the RBCA process:

1. It is generally impractical (from both technology and cost standpoint) to remove all contamination to background levels;

2. Aggressive remediation is not required to protect human health and the environment at all sites;

3. Natural attenuation of contamination and/or other disturbance factors occurs at many sites once the source of the disturbance is stopped;

4. Not all shallow waters are used as a source of drinking water; and

5. Risk management (i.e. combination of engineering and institutional controls) is often a practical and effective solution in many instances.

The RBCA process is implemented in a tiered approach that involves increasingly sophisticated levels of data collection and analysis (ASTM, 1996), where "the assumptions of earlier tiers are replaced with site-specific data and information". The user is required to identify the sources of the chemical(s) of concern, obvious environmental impacts (if any), and potentially impacted humans and environmental receptors (i.e. workers, residents, water bodies, etc.), and potentially significant transport pathways. Much of the information required to apply the process described in this Workbook is identical that which is typically collected during the early stages of Tier 1 of the RBCA process, involving the identification of reasonable potential sources, transport pathways, and potential receptors. As such, the Workbook may be viewed essentially as a "Tier 0 " activity within the RBCA process.

\subsubsection{EPA Proposed Guidelines for Ecological Risk Assessment - Ecological risk} assessment is a qualitative evaluation of the actual or potential impacts to environmental (i.e. nonhuman) receptors. However, there may be circumstances where a more detailed risk assessment may be necessary. Risk assessment is a sicientifically-based process that estimates human 
health and environmental risks associated with chemicals(s) of concern present in the environment. Adverse effects or risk depend on both toxicity and exposure. Exposure involves factors associated with the source, pathways, and the receptor(s) of interest.

Issued in August 1996, the EPA's proposed guidelines for ecological risk assessment (ERA) were intended to help improve the quality and consistency of the ERA process. EPA defines ERA as "The process that evaluates the likelihood that adverse ecological effects may occur or are occurring as a result of exposure to one or more stressors" (USEPA 1992).

Within the context of this definition:

- $\quad$ "likelihood" implies that descriptions of risk may range from qualitative judgements to quantitative probabilities. While risk assessments may include quantitative risk estimates, current science may not support such quantification. EPA therefore considers it preferable to convey the relative magnitude of uncertainties to a decision maker qualitatively rather than ignoring them because of difficulties in measuring or estimating them.

- "adverse ecological effects" imply anthropogenically-induced changes that are considered undesirable because they, alter the structure and/or function of ecological systems. The type, intensity, and scale of the effect should be considered, as well as the potential for recovery.

- "may occur or are occurring" indicate that ERAs may be prospective or retrospective. Retrospective ERAs evaluate the likelihood that observed ecological effects are associated with previous or current exposure to stressors. Many of the same methods and approaches are used for both prospective and retrospective assessments, and in the best case, even retrospective assessments contain predictive elements linking sources, stressors, and effects.

- "one or more stressors" indicates that ERA may address single or multiple chemical, physical, or biological stressors. Because risk assessments are conducted to provide input to management decisions, the focus is on stressors generated or influenced by anthropogenic activities.

According to EPA, the ERA process includes three primary phases:

1. Problem formulation: This involves the identification of goals and assessment endpoints, preparation of conceptual models, and development of an analysis plan.

2. Analysis phase: This involves evaluation of exposure to stressors and the relationship between stressor levels and ecological effects. The analysis phase also includes a technical evaluation of data to reach conclusions about ecological exposure and the relationships between the stressor and ecological effects. Two general activities are included in the Analysis phase: characterization of exposure and characterization of ecological effects.

3. Risk characterization: Key elements are used to estimate risk through integration of exposure and stressor-response profiles, describing risk by discussion lines of evidence and determining ecological adversity, and preparing a report.

Assessment endpoints that cannot be measured directly but can be represented by 
measures that are easily monitored and modeled still provide a good foundation for ERA. Assessment endpoints provide a transition tetween broad management goals and the specific measures used in an assessment. They help assessors identify measurable attributes to quantify and predict change. Assessment endpoints also help the risk assessor determine whether management goals have been or can be achieved. Two elements are required to define an assessment endpoint. The first is the ecological entity of concern. This can be a species, a functional group of species (e.g. raptors), an ecosystem function or characteristic (e.g. nutrient cycling), a specific valued habitat (e.g. wet meadows) or a unique place (e.g. a remnant of a native prairie). The second is the characteristic about the entity of concern that is important to protect and potentially at risk. For an assessment endpoint to provide a clear interpretation of the management goals and the basis for measurement in the risk assessment, both an entity and an attribute are required.

The objective of this Workbook is to provide a screening procedure that will allow for the prioritization of sites for characterization and remediation. As such, the EPA ERA process is too detailed for application here. However, beceluse the ERA process is one that will likely follow the screening procedure for the sites that most need remediation, the Workbook draws from EPA guidance to facilitate subsequent ERA activities.

\subsubsection{U.S. Fish and Wildlife Service Contaminant Monitoring Program - A} comprehensive Workbook for developing and implementing contaminant monitoring on U.S. wildlife refuges was developed by the Idaho National Engineering and Environmental Laboratory (INEEL) for the U.S. Fish and Wildlife Service (FWS). This FWS Workbook is currently being used to establish monitoring programs on FWS-managed lands throughout the U.S. Pertinent aspects of the FWS contaminant monitoring Workbook are being incorporated into the petroleum E\&P site prioritization Workbook. 
1.2 TOXICITY ASSOCIATED WITH PETROLEUM E\&P SITES -- Toxic contamination of soil and water resulting from petroleum drilling and production sites results primarily from the discharge of drilling fluids and crude petroleum (Carls et al., 1995). To a lesser extent, spills of refined petroleum products (i.e. fuels and lubricants used in machinery and equipment) may occur. A non-comprehensive summary of toxic contaminants commonly used during E\&P activities is provided in Table 1-1. Although contamination of soils from these sources may be widespread and persistent at oil and gas drilling and productions operations, contamination is generally restricted to the immediate vicinity of drilling and production activity. 


\section{Table 1-1. Partial Summary of Toxic Coritaminants Potentially Associated with Petroleum} Exploration and Production Facilities.

I. Drilling muds or drilling fluid additives

A. Metals

1. $\mathrm{Cr}$

2. $\mathrm{Ba}$

3. $\mathrm{Pb}$

4. $\mathrm{Zn}$

B. Biocides

1. formaldehyde

2. paraformaldehyde

3. chlorinated phenols (e.g. sodium pentachlorophenate)

4. insecticides (various - to control insects in mud pits?)

C. Salts

1. potassium chloride

2. sodium (e.g. as $\mathrm{NaOH}$ in high $\mathrm{pH}$ lime muds)

D. Corrosion control

1. ammonium bisulfate $\left(\mathrm{NH}_{4} \mathrm{HSO}_{3}\right)$

2. sodium bisulfate $\left(\mathrm{NaHSO}_{3}\right)$

3. calcium carbonate $\left(\mathrm{CaCO}_{3}\right)$

4. sodium acid pyrophosphate $\left(\mathrm{N}_{2}\left(\mathrm{HPO}_{4}\right)_{2}\right)$

5. caustic soda

6. white lime

II. Crude petroleum (many different hydrocarbons with differing properties)
A. light aromatics (benzene $\rightarrow$ naphthalene)
B. high molecular weight hydrocarbons
C. metals (trace quantities)
D. total petroleum hydrocarbons (TPH)

III. Miscellaneous

A. radium ( $\rightarrow$ radon) in barite scales in production pipe, equipment

B. refined products (gasoline, kerosene, fuel oils, lubricating oils)

1. benzene (carcinogenic)

2. benzo(a)pyrene (carcinogenic)

3. EDB (ethylene dibromide - carcinogenic)

4. EDC (ethylene dichloride - carcinogenic).

5. Other PAHs (poly aromatic hydrocarbons e.g. benzo(s)pyrene)

6. ethylbenzene

7. xylene

8. MTBE (methyl tributyl ethylene)

9. TBA (tributyl amine)

10. MEK (methyl ethyl ketone)

11. MIBK (methyl isobutyl ketone)

12. lead 
1.2.1 Drilling Fluids ("muds") -- Drilling muds or drilling fluids are slurries that are used in the drilling process. Essentially, they are a barite clay mixed either with water (brine or fresh water) or with some oil-based medium. The primary purpose of drilling muds are to provide a medium in which drill cuttings may be lifted to the surface. Muds also help cool the drilling surface, lubricate the pipe, and maintain a balance of pressure on the pipe.

Muds are used in most, but not all drilling operations (i.e. some drilling operations are done "dry"). Both water-based and oil-based muds generally use barite clay as the solid material, which is where the barium come from in the formation of scale. Oil-based muds are generally only used for special operations. They are more expensive, and also necessitate the use of surfactants and emulsifiers in addition to other additives. Although most drilling fluids are water-based (either fresh- or saltwater), approximately 5 to $10 \%$ of the muds used are oil-based (Chilingarian and Vorabutr, 1981). Diesel oil is the most common of the oil bases, and these muds are generally used only under special drilling conditions.

Gettleson (1980) estimated that there are about 55 materials that are commonly used as additives to drilling muds, although only about 10 to 15 predominate. These additives are used to convey a specific property (Kanz and Cravey, 1987). Most additives are used for one of the six purposes listed below:

- Increase fluid density: primarily barite $\left(\mathrm{BaSO}_{4}\right)$;

- Increase fluid viscosity: primarily bentonite clays;

- Thinning agents: e.g. lignite or lignosulfonates

- Control pH: e.g. caustic soda, $\mathrm{NaOH}$ and white lime, $\mathrm{Ca}(\mathrm{OH})_{2}$;

- Control corrosion: e.g. ammonium bisulfate $\left(\mathrm{NH}_{4} \mathrm{HSO}_{3}\right)$, sodium bisulfate $\left(\mathrm{NaHSO}_{3}\right)$, calcium carbonate $\left(\mathrm{CaCO}_{3}\right)$, sodium acid pyrophosphate $\left(\mathrm{N}_{2}\left(\mathrm{HPO}_{4}\right)_{2}\right)$, caustic soda, and white lime;

- Control bacterial growth (biocides): e.g. formaldehyde, paraformaldehyde, chlorinated phenols.

The specific composition of drilling fluids used is dependent on the properties of the specific geological formations and drilling conditions encountered. Mixtures therefore vary not only between sites, but also change with borehole depth. The fluids used in drilling an individual well are therefore distinctive in composition, resulting in different potential contaminant problems at each drilling site.

Muds are generally recycled by using a "mud pit". In recent years, the mud pits have been lined, but most older facilities used unlined pits. Materials pumped up during the drilling operation 
are dumped into the pit. Solids (i.e. rock fragments) are removed, and the mud is reused. Historically, at the end of operations, the pit was generally abandoned with the residual material remaining. Toxicological problems with water-based muds are largely due to additives.

Drilling fluids may be lost to the environment during drilling operations, and at disposal. For water-based muds, a common disposal technique involves correcting for $\mathrm{pH}$ and ion (especially $\mathrm{Cl}$ ) content and then spreading the material over adjacent land areas. Other drilling fluids may be stored on-site in pits and subsequently buried either on-site or at a designated regional disposal site. Oil-based muds are usually resold to mud companies for recycling.

The fate and effects of drilling fluids released to the environment depends on several factors, including the amount and composition of the various materials added to the fluids, and their interaction with the ambient environment. As indicated above, the primary solid materials present in drilling fluids are barite and bentonite. These substances are essentially insoluble, inert, and non-toxic (Monaghan et al., 1980), and result only in an alteration of the physical characteristics of the soils. However, many of the additives to drilling fluids are toxic, and may be of concern when released to the environment. Among the primary environmental concerns with drilling fluids are toxic heavy metals, most of which are associated with barite and bentonite additives. As indicated above, barite and bentonite are highly insoluble, which tends to immobilize the metals contained therein. However, metals may slowly be released from soils and sediments that contain large quantities of barite and bentonite. Although many metals may be found in drilling fluids, four ( $\mathrm{Cr}, \mathrm{Ba}, \mathrm{Pb}$, and $\mathrm{Zn}$ ) generally occur in highest concentrations in most commercial muds (Carls et al., 1995).

Drilling muds with high concentrations of salts (e.g. potassium chloride muds) and/or sodium (e.g. as $\mathrm{NaOH}$ in high pH lime mud:s) are potential contaminants of concern. Similarly, substances added to control corrosion, such as ammonium bisulfate $\left(\mathrm{NH}_{4} \mathrm{HSO}_{3}\right)$, sodium bisulfate $\left(\mathrm{NaHSO}_{3}\right)$, calcium carbonate $\left(\mathrm{CaCO}_{3}\right)$, sodium acid pyrophosphate $\left(\mathrm{N}_{2}\left(\mathrm{HPO}_{4}\right)_{2}\right)$, caustic soda, and white lime may result in contamination of the environment.

Among the most toxic constituents of drilling muds are the compounds added as biocides. These include bactericides added to prevent microbial degradation of organic additives and to suppress the formation of hydrogen sulfide by sulfate-reducing bacteria. Active ingredients are usually either formaldehyde, paraformaldehyde, or a chlorinated phenol (e.g. sodium pentachlorophenate). Insecticides may also be added in some cases. Although the toxicity of these materials are very high, they are added in very small concentrations to the drilling muds.

An operational history of each drill site is needed before determining monitoring needs. Detailed information on the muds used in the drilling operation (including all potentially important 
additives) and the disposal of these muds is needed. Neff (1982) estimated that an average production well uses from 100 to 400 metric tons of drilling fluids, indicating that the release and accumulation of mud additives in the environment may be a matter of volume as well as concentration.

Carls et al. (1995) found elevated concentrations of the metals $\mathrm{Ba}, \mathrm{Cr}, \mathrm{Pb}$, and $\mathrm{Zn}$ in soils in a production area in Texas. Levels of $\mathrm{Na}$, salinity, and $\mathrm{pH}$ were also measured as indicators of contamination by drilling fluids high in $\mathrm{Na}$, salt, and certain corrosion control agents (e.g. caustic soda).

1.2.2 Crude Petroleum - Contamination with crude petroleum is a fairly common occurrence at sites of producing wells. Crude oil consists of hundreds to thousands of individual hydrocarbon chemicals of varying molecular size and organization, toxicity, and environmental mobility. In general, as the molecular mass of hydrocarbons increases, viscosity increases, volatility and water solubility decreases, and bioavailability decreases (Sullivan and Johnson, 1993). The light aromatics (benzene $->$ naphthalene) are considered to be the most immediately toxic components of petroleum, but refined products usually have higher concentrations of soluble aromatic hydrocarbons (McDonald et al., 1984). Normally, the more volatile hydrocarbons $\left(<\mathrm{C}_{15}\right)$ in crude oil or in refined products are lost from exposed spills in a matter of days. High molecular weight hydrocarbons also exhibit stronger adhesion to soils and less mobility in the subsurface. As a result, the heavier, less volatile hydrocarbon fractions persist longer in the environment.

Crude oil may also contain toxic metals, although in fairly small concentrations. Barite scales formed in production piping and equipment may also contain substantial concentrations of radium, which may result in the emanation of radon.

As with the drilling fluids, the fate effects of petroleum hydrocarbons when released to the environment depends on the amount and composition of the material and its interaction with the ambient environment. Because crude oil is not a homogeneous mixture, and because the most toxic compounds in the mix are readily lost through volatilization, environmental assessments of crude oil contamination at drilling sites is often based on some analysis of "total petroleum hydrocarbons" (TPH). This may be performed by a variety of analytical methods which, as the name suggests, report the total amount of hydrocarbons present as a single number without providing information on the types of hydrocarbon present. As such, its utility may be somewhat restricted. However, for spills of crude oil, TPH can be a useful indicator of contamination.

Additional analyses examined the amount and condition of petroleum hydrocarbons found in soil samples collected at drilling and production sites. Carls et al. (1995) reported high levels of 
petroleum hydrocarbons in soil samples at production sites in Texas. Associated gas chromatograms demonstrated that petroleum contamination events were unique, indicating that the resulting environmental fate and effects will vary for different spill events.

1.2.3 Refined Petroleum Products -- In drilling operations, refined petroleum products are used in the operation of machinery and equipment, and involve gasoline, kerosene, fuel oils, and/or lubricating oils. Refined petroleum products represent a very small fraction of the total quantity of contaminants released to the environment at a drilling site. Although these spills are generally localized, they may contain high concentrations of aromatic hydrocarbons or other toxic materials (Table 1-2). Most trace metals found in crude oil are removed by the refining process. However, some (e.g. lead) may be added to refined products.

For spills of refined petroleum products, TPH methods should be limited to the identification of contamination boundaries and location of "hot spots". However, TPH analyses do not allow for the determination of individual constituents, and so are of limited value for refined petroleum products because they provide insufficient information about the amounts of individual compounds present.

Benzene and benzo(a)pyrene (and in some cases EDB and EDC) are often used as indicator compounds for refined petroleum products because they are known to be carcinogenic. Other PAHs may also be grouped with benzo(s)pyrene because of uncertainties in their carcinogenicity and because they may accumulate (bioconcentrate) in living tissue (ASTM, 1995).

Table 1-2. Commonly selected indicator compounds for petroleum fuels (ASTM, 1995).

Benzene

Toluene

Ethylbenzene

Xylene

MTBE, TBA, MEK, MIBK, methanol, ethanol

Lead, EDC, EDB

PNAs

\section{Unleaded}

Gasoline

$$
X
$$

$x$

$x$

$x_{1}$
Leaded

Gasoline

$X$

$X$

$x$

$\mathrm{X}$

$x$

\section{Kerosene/}

Jet fuels

$x$

$x$

$x$

$x$
Diesel/light

fuel oils
Heavy

fuel oils

'When suspected (e.g. when they may have been present in the spilled gasoline. These additives are not present in all gasolines). 
1.2.4 RCRA-Regulated Wastes - Wastes that are "uniquely associated with oil and gas exploration and production operations" are specifically exempt from regulation under Subtitle $C$ of the RCRA hazardous waste regulations. These include "drilling fluids, produced water, and other wastes associated with the exploration, development or production of crude oil or natural gas." Most wastes that are regulated under RCRA are hazardous wastes generated by service contractors.

1.2.5 NORM Wastes -- Drilling operations generate small quantities of naturally occurring radioactive materials (NORM). Wastes containing NORM are generated when drill pipes are cleaned to remove the scale that accumulates on the surfaces. Depending on the uranium and thorium content of the strata through which the core was drilled, the scale may contain small quantities of these materials and their radioactive daughter products (including radium and radon).

1.2.6 Associated Wastes -- This include all other types of wastes generated by various processes associated with oil and gas production. At Prudhoe Bay, for example, approximately 650,000 barrels of associated wastes are produced each year. Most of these wastes are waterbased wastes containing suspended solids and oil. Some of the "associated wastes" are potentially hazardous due to their hydrocarbon content. These wastes are covered by the RCRA oil and gas exemption, and include the following;

- Tank bottom sludges,

- Spill residues and contaminated soils,

- Truck/tank/cellar wastewaters,

- Dehydration unit wastes from the gathering centers,

- Pipeline pigging wastes,

- Wastes from well workovers

- Miscellaneous wastes. 


\subsection{PHYSICAL DISTURBANCE AT PETROLEUM E\&P SITES - Disturbance at}

petroleum E\&P sites can also be of a physical rather than a chemical nature. For this reason, it is appropriate to consider mechanisms of phy:sical damage to E\&P sites when determining the need for remediation. Physical disturbance may be associated with exploration (e.g. road construction, seismic lines), drilling (pad construction, mud pits), and production (e.g. pumps, gathering stations, tanks).

Physical disturbance at petroleum E\&P sites can range from the simple removal of vegetation by burning or trampling to the construction of permanent features. The surface disposal or storage of produced waters, ancl drilling muds and cuttings can also create a physical disturbance, although each of these factors may have a toxic component as well.

Some of the more commonly encountered mechanisms of physical disturbance at E\&P sites are briefly described below.

1.3.1 Removal of Vegetation and/or Soil - The removal of vegetation can result in the direct loss of habitat. If other factors such as the introduction of toxic materials are eliminated, the vegetation will usually return, so long as the soil is not disturbed. However, the composition of the regenerated plant community may be substantially different from the pre-disturbance community for a variety of reasons.

Removal of the soil may result in greater damage to the ecological system, and may effectively prevent the reestablishment of plant communities even if active measures are taken. The degree of damage is proportional to the depth to which the soil is removed, which varies spatially. Even when not removed, soil can be damaged by compaction from heavy equipment.

1.3.2. Sedimentation of Streams - A secondary effect potentially resulting from the removal of vegetation or soil is increased soil erosion. If severe enough, this can result in an increase in the sediment loads carried by streams draining the site. In this manner, damage to the terrestrial environment may subsequently cause damage to the aquatic environment.

1.3.3 Spills of Crude Oil -- Although spills of crude oil include a significant toxic component, much of the damage to aquatic and terrestrial systems from oil spills is physical. Oil can create a physical barrier to plants and animals. In plants, oil spills can prevent gas exchange into and out of leaf tissues, and prevent seedling establishment and root growth. Respiration in many animals can be prevented in many animals. 
1.3.4 Disturbance from E\&P infrastructure - The construction of roads, pipelines, drill pads, and other infrastructure cause a physical disturbance simply by displacing the plant and animal life present. Although the total area covered by infrastructure at an E\&P site is generally fairly small, these areas are more or less permanently impacted, unless active restoration measures are taken.

1.3.5 Disposal of Drill Cuttings - At some E\&P sites, drill cuttings are disposed of on site. Even if these materials are free of crude oil or other contaminants, their accumulation on site may result in a considerable area of physical disturbance.

\subsubsection{Disposal/Storage of Produced Waters - Brines or waters that come to the} surface with the oil are separated from the oil. Often, produced waters are reinjected into the oil producing reservoir. In older E\&P operations, however, produced waters were often placed in large pits or holding ponds. The storage or disposal of these produced waters at the surface may result in both chemical and physical disturbance.

1.3.7 Storage of Drilling Muds -- As with produced waters, the collection of drilling muds in surface pits may result in both a toxic and physical disturbance. 


\subsection{WORKBOOK FOR PRIORITIZING E\&P SITES FOR REMEDIATION}

Evaluation of each individual petroleum exploration or production site is a two step process. The first step is to complete a "Facility or Site Description Worksheet" for the site. This is followed by the application of the "Petroleum E\&P Remediation User's Guide" in which the site is assigned numerical scores to various Evaluation Factors. The final score assigned to an individual site may then be used to determine the relative need for remediation.

2.1 FACILITY/SITE DESCRIPTION WORKSHEET -- The facility/site description worksheet, an example of which is provided below, shculd be completed for each site. The purpose of the worksheet is to summarize the basic information about the site, including ownership, location, operational history, etc.

The worksheet should be accompanied by considerable additional information about the site and the surrounding areas that will be used to apply the User's Guide. Wherever possible, this ancillary information should include the following:

- aerial photos and/or maps of the site, including biophysical and land use maps;

- historical information on site activities;

- information on site conditions, including documented environmental impacts due to activities at the site;

- measures or systems in place at the site to protect human health and the environment.

- summaries of rainfall, wind, and other meteorological data;

- summaries of local and regional census data;

- records of water wells and water usage in the area surrounding the site. 


\section{FACILITY/SITE DESCRIPTION WORKSHEET}

Document site information as completely as possible:

Site Custodian:

Facility Name:

Type of Site:

UTM Coordinates:

Location:

Address:

Brief description of site:

Site Land Use: Current:

Proposed:

Comments:

Summary of Site Classification Information: Completed Evaluation Form:

Class:(1,2,3, $\overline{\mathrm{N}, \text { or } \mathrm{I}}$ Risk:

Contact Name:

Site Name:

Site Operator/Manager:

Site Owner:

Latitude: _deg. _min. _sec.

Longtitude: _ deg. __min. __sec.

Legal Description:___ (Township)

State/County:

Address:

Phone: Fax:

Notes:

Site Classified by above:

or:

Degree of familiarity with site:

Position:

Phone:

Address:

Date of classification:

Position: 
2.2 PETROLEUM E\&P REMEDIATION USER'S GUIDE - The User's Guide is a detailed evaluation form that includes scoring guidelines and "fill-in-the-blank" sections for tallying the scores. For toxic or radioactive contaminants, this is based on characteristics associated with:

1. the contaminants of concern;

2. the pathways by which the contaminants are transported; and

3. the receptors of concern that are exposed to the contaminants.

For physical disturbances, scores are determined for characteristics associated with:

1. the degree to which the disturbance occurs;

2. the physical extent of the disturbance; and

3. the significance of the resources that are disturbed.

It is understood that some of the information necessary to apply the User's Guide may not be readily available. In such cases, a "best estimate" must be made. While applying the User's Guide to score a site, it should be remembered that different E\&P sites are not ranked numerically against one another. Rather, the ultimate goal is to assign each site to a "Site Classification Category" (e.g. "high", "medium", or "low") based on the relative score received by the site. It should also be mentioned that users can "streamline" the Workbook by focusing on a subset of Environmental Factors. Furthermore, users may alter the scoring values suggested in the Workbook as they deem necessary.

Because no two contaminated E\&P sites are identical, it is difficult to design a generic classification system that addresses all possible circumstances potentially affecting the total hazard associated with a site. Rather, sites may possess conditions or situations that are not adequately represented by the evaluation factors in the User's Guide. For this reason some flexibility has been incorporated into the User's Guide with the user having discretion to slightly increase or decrease the site score within pre-defined limits by applying "special considerations" to the score within each category of characteristics. The intent of these special considerations is to allow the user sufficient flexibility to address unique site conditions or to emphasize important concerns about a site and should be used as an exception rather than a rule.

Within a category, special considerations scores may be applied that are either positive 
(i.e. added) or negative (i.e. subtracted) to emphasize or deemphasize the importance of certain concerns about a particular site. For example, a sensitive population habitat near a site may require that special considerations scores be added to the receptor category score to account for this. The evidence and rationale behind selection of any special considerations scores must always be clearly documented in the Workbook.

The following sections outline the evaluation process using a wide variety of evaluation factors. For each group of factors, and Action is given which is intended to provide a concise statement of what information is needed to score the group of evaluation factors. This is followed by a matrix used to determine the score for the set of evaluation factors. Included within the matrix is a column where the evaluator can provide comments. The "comments" column should be used throughout the process to document the rationale used by the evaluator in assigning numerical values to each Evaluation Factor. The "Uncertainty" column is intended to provide the user with a place to note, in relative terms, how confident he or she is of the information upon which the numerical score is based.

Following the evaluation factor matrix is a brief description of the "Method of Evaluation" which provides the user with a brief description of how to go about determining the scoring for each factor. Suggested "primary sources of information" are also provided for each factor, although in most cases other valid information sources are also available.

Finally, a line is available at the end of each section where the score for the set of evaluation factors may be recorded. 
2.2.1 PETROLEUM E\&P SITE EVALUATION FACTORS - The evaluation factors for petroleum E\&P sites relate to both contaminants and physical disturbance. Those associated with contaminants involve characteristics of the contaminants themselves, the means by which the contaminants are transported in the environment, and the potential receptors of those contaminants. With respect to physical disturbance, evaluation factors deal with the degree of disturbance, the physical or geographical extent of the disturbance, and the relative significance of the resources that are disturbed. Physical clisturbance Evaluation Factors are treated separately in Section 2.2.1.4.

2.2.1.1 Contaminant characteristics: The first set of characteristics to be considered at a petroleum E\&P site are those associated with toxic contaminants known or suspected to be found at the site. For most E\&P sites, this will be based on readily available operational records for the facility in question. Difficulties may be encountered in reconstructing contaminant scenarios for facilities that have been out of production for long periods, especially if ownership has changed.

A. Degree of Hazard: The degree of hazard associated with contaminants is a function of the quantity, relative toxicity, and physical form of contaminants anticipated to be found at a facility. For petroleum E\&P sites, this largely involves determining what muds and additives were used, and how these muds were disposed. In determining the degree of hazard of a contaminant, a RCRA-listed hazardous waste is generally of higher concern than non-listed wastes.

Action: List possible contaminants and estimated relative concentrations in various media found on site, and determine the relative toxicity of each known contaminant.

\begin{tabular}{|c|c|c|c|c|}
\hline \multicolumn{5}{|c|}{ EVALUATION FACTORS FOR DEGREE DF HAZARD' } \\
\hline $\begin{array}{l}\text { CONCERN } \\
\text { (i.e. relative } \\
\text { toxicity) }\end{array}$ & CONCENTRATION & $\begin{array}{l}\text { SCORING } \\
\text { GUIDELINE }\end{array}$ & COMMENTS & $\begin{array}{c}\text { UNCERTAINTY } \\
(\mathrm{H}, \mathrm{M}, \mathrm{L})\end{array}$ \\
\hline High toxicity & High concentration & 14 & & \\
\hline High toxicity & Low concentration & 11 & & \\
\hline $\begin{array}{l}\text { Medium } \\
\text { toxicity }\end{array}$ & High concentration & 8 & & \\
\hline $\begin{array}{l}\text { Medium } \\
\text { toxicity }\end{array}$ & Low concentration & 5 & & \\
\hline Low toxicity & -- & 3 & & \\
\hline \multicolumn{5}{|c|}{ 'Adapted from Canadian National Classification System for Contaminated Sites } \\
\hline
\end{tabular}


Method of Evaluation: Determine the level of hazard according to the following categories of contaminants:

1. Determine or estimate the relative concentrations of each contaminant.

2. Determine the relative toxicity of each (high, medium, or low):

High Concern Contaminants: These primarily include RCRA-listed toxic materials such as metals, pesticides, acid solutions, and solvents.

Medium Concern Contaminants: Contaminants of medium concern include non-listed materials such as crude oil and petroleum products.

Low Concern Contaminants: The low concern contaminants include solid (non-toxic) wastes. "Clean" drill cuttings are included in this category.

Primary sources of information: Toxicity values for a chemicals are available from a wide variety of sources. A list of possible sources of toxicity information is provided below, in order of general preference (i.e. acceptance) as suggested by ASTM.

1. State specific toxicity values

2. IRIS (Integrated Risk Information System). Contains only values that have been reviewed by EPA, with no external peer review of safe dose estimates.

3. HEAST - health effects assessment summary tables

4. EPA Criteria Documents

5. ATSDR - Agency for Toxic substances and Disease Registry

6. World Health Organiazation

7. Canadian Government published values

8. Peer-reviewed literature

SCORE 
B. Contaminant quantity: The need for remediation is related to the total amount of contamination found at the site. Ideally, this information should be provided in terms of the total volume or mass of each contaminant present on the site. In many cases, however, volume or mass information will not be available, in which case estimates of the area contaminated may be used. For example, information may be lacking for abandoned E\&P sites, at which estimates of the area contaminated should be used.

Action: Document (via records, estimates, or direct measurements) the total volume and/or area of contamination present at the site.

\begin{tabular}{|c|c|c|c|}
\hline \multicolumn{4}{|c|}{ EVALUATION FACTORS FOR CONTAMINANT QUANTITY' } \\
\hline EVALUATION FACTOR & $\begin{array}{l}\text { SCORING } \\
\text { GUIDE:LINE }\end{array}$ & COMMENTS & $\begin{array}{c}\text { UNCERTAINTY } \\
(H, M, L)\end{array}$ \\
\hline $\begin{array}{l}\text { Contaminant volume }>1000 \mathrm{~m}^{3} \\
\quad \text { OR } \\
\text { Area contaminated }>10 \mathrm{ha} \\
\quad \text { OR } \\
\text { Drums of waste present }\end{array}$ & 10 & & \\
\hline $\begin{array}{l}\text { Contaminant volume } 100 \text { to } 1000 \mathrm{~m}^{3} \\
\text { OR } \\
\text { Area contaminated } 2 \text { to } 10 \mathrm{ha}\end{array}$ & 6 & & \\
\hline $\begin{array}{l}\text { Contaminant volume }<100 \mathrm{~m}^{3} \\
\quad \text { OR } \\
\text { Area contaminated }<2 \text { ha }\end{array}$ & 2 & & \\
\hline
\end{tabular}

Method of evaluation: Use operational records, if available, to determine the total volume of each contaminant of concern found at the site. If volume data is not available, measure or estimate the volume or area of potential contamination. Note: If any drums of wastes have been abandoned at the site, this criterion should receive a "high" rank.

Primary sources of information sources: Site operational records, where available, on (1) drilling muds used (quantity and additives); (2) disposal of muds; (3) disposal/storage of produced waters; (4) disposal of other wastes; and (5) quantity and location of known crude oil spills. Direct measurements where appropriate.

\section{SCORE}


C. Physical state of contaminants: The physical state of a contaminant present at a site will influence the capacity for migration of the contaminant from the site. Contaminants in liquid form are more mobile in the ground and water than solids. However, certain water-soluble solid wastes are more mobile than viscous liquids, and these should be evaluated on a case-by-case basis.

Action: Determine whether contaminants at the site are:

- Predominantly liquids/gases:

- Primarily sludges:

- Primarily solids:

\begin{tabular}{|l|c|c|c|}
\hline \hline EVALUATION FACTORS FOR PHYSICAL STATE OF CONTAMINANTS' \\
\hline $\begin{array}{l}\text { EVALUATION } \\
\text { FACTOR }\end{array}$ & $\begin{array}{l}\text { SCORING } \\
\text { GUIDELINE }\end{array}$ & COMMENTS & $\begin{array}{c}\text { UNCERTAINTY } \\
\text { (H, M, L) }\end{array}$ \\
\hline $\begin{array}{l}\text { Predominantly } \\
\text { liquids or gases }\end{array}$ & 9 & & \\
\hline Primarily sludges & 7 & & \\
\hline Primarily solids & 3 & \\
\hline 'Adapted from Canadian National Classification System for Contaminated Sites \\
\hline
\end{tabular}

Method of evaluation: Determine the state of the contaminant when it was disposed or deposited.

Primary sources of information: Site operational records, where available, on (1) drilling muds used (quantity and additives); (2) disposal of muds; (3) disposal/storage of produced waters; (4) disposal of other waste materials; and (5) quantity and location of known crude oil spills. 
D. Special Considerations for Contaminant Characteristics: Conditions or situations relating to the characteristics of the contaminants found at the site that are not represented by the evaluation factors listed above may be considered here. These "special considerations" factors are intended to allow the user sufficient flexibility to address unique contaminant conditions or to emphasize important concerns relating to contaminants. These special considerations are intended to be used as an exception rather than a rule.

Action: Document any other important coritaminant characteristics not addressed above.

Score guidelines: Special considerations can alter the total score for Contaminant characteristics by \pm 6 points.

Primary sources of information: Technicial judgment of the evaluator. Input from other interested parties.

SCORE 
2.2.1.2 Exposure Pathways - This second group of characteristics relate to the means by which contaminants move from the site to areas beyond the property boundary. For contaminants associated with petroleum exploration and production activities, most pathways involve either surface or groundwater. Off-site migration of contamination should be prevented.

A complete assessment of an exposure pathway requires the identification of (1) a source and mechanism for chemical release into the environment; (2) a transport medium (i.e. air, soil, groundwater) for the chemical to move from the source to the receptor; (3) a point of potential contact of the receptor with the medium; and (4) an uptake route or means for taking the chemical into the receptor (i.e. ingestion, inhalation, dermal contact, etc.).

A. Groundwater: Unless adequately contained, contaminants can move downward in the soil column until they come into contact with the groundwater. At this point, contaminants may migrate beyond the boundary of the site along with the groundwater. Eventually, these contaminants may reach wells providing drinking water, irrigation, or industrial use. Prevention is the key to the protection of groundwater resources, as cleanup of contaminated aquifers can be extremely costly. Among the characteristics to be assessed regarding groundwater are:

1. the known presence contamination at or beyond the property boundary; and

2. the potential for groundwater contamination to result from the site. 
1. Known contamination at or beyond property boundary: If groundwater contamination is known to occur beyond the property boundary, the following factors relating to the extent of this contamination should be assessed.

Action: Document information on known extent of groundwater contamination originating at the site. Evaluate available data against U.S. Environmental Protection Agency Safe Drinking Water Standards (SDWS).

\begin{tabular}{|c|c|c|c|}
\hline \multicolumn{4}{|c|}{$\begin{array}{l}\text { EVALUATION FACTORS FOR KNOWN GROUNDWATER CONTAMINATION AT OR } \\
\text { BEYOND PROPERTY BOUNDARY }{ }^{1}\end{array}$} \\
\hline EVALUATION FACTOR & $\begin{array}{l}\text { SCORING } \\
\text { GUIDELINE }\end{array}$ & COMMENTS & $\begin{array}{l}\text { UNCERTAINTY } \\
(\mathrm{H}, \mathrm{M}, \mathrm{L})\end{array}$ \\
\hline $\begin{array}{l}\text { Groundwater contaminant } \\
\text { concentrations exceed SDWS by }>2 x\end{array}$ & 11 & & \\
\hline OR & & & \\
\hline \multicolumn{4}{|l|}{$\begin{array}{l}\text { Contaminants are known to be in } \\
\text { contact with groundwater }\end{array}$} \\
\hline \multirow{3}{*}{$\begin{array}{l}\text { Groundwater contaminant } \\
\text { concentrations are between } 1 \text { and } 2 x \\
\text { SDWS } \\
\qquad \text { OR } \\
\text { Contaminants are suspected to be in } \\
\text { contact w/groundwater }\end{array}$} & 6 & & \\
\hline & & & \\
\hline & & & \\
\hline $\begin{array}{l}\text { No contaminants in groundwater } \\
\text { exceed SDWS }\end{array}$ & 0 & & \\
\hline
\end{tabular}

Method of Evaluation: Review groundwater monitoring data, where available, and evaluate groundwater quality. If contamination at or beyond the property boundary exceeds EPA Safe Drinking Water Standards, or if contaminants are known to be in contact with groundwater, evaluate as high.

Primary sources of information: Groundwater monitoring data on- or off-site. U.S. Environmental Protection Agency, and state and local water quality boards.

\section{SCORE}


2. Potential for groundwater contamination. Well-contained sites have minimal potential for contamination migration. Several factors relate to the potential for groundwater contamination from a site. These include (a) engineered subsurface containment barriers; (b) the thickness of the confining layer over aquifer(s) of concern; (c) the amount of rainfall received annually; and (d) the hydraulic conductivity of aquifer(s) of concern.

a. Engineered subsurface containment: Hazardous waste disposal facilities typically employ some form of engineered containment structure to prevent the downward migration of contaminants. At petroleum E\&P sites, impermeable liners may be used in the construction of reserve pits.

Action: Document engineered systems designed to prevent migration to the groundwater.

\begin{tabular}{|l|c|c|c||}
\hline \hline \multicolumn{2}{||l|}{ EVALUATION FACTORS FOR ENGINEERED SUBSURFACE CONTAINMENT } \\
\hline $\begin{array}{l}\text { EVALUATION } \\
\text { FACTOR }\end{array}$ & $\begin{array}{c}\text { SCORING } \\
\text { GUIDELINE }\end{array}$ & COMMENTS & $\begin{array}{c}\text { UNCERTAINTY } \\
(\mathbf{H}, \mathbf{M}, \mathrm{L})\end{array}$ \\
\hline No containment & 4 & & \\
\hline Partial containment & 2 & & \\
\hline Full containment & 0 & & \\
\hline Adapted from Canadian National Classification System for Contaminated Sites \\
\hline
\end{tabular}

Method of evaluation: Review the existing engineered systems (i.e. berms, covers, pond linings, etc.) and relate these to the hydrogeology of the site and determine if full containment of contaminants is achieved. Full containment is defined as an effective engineered system which provides for the capture and treatment of contaminants. If there is no system, this factor is evaluated high. If there is less than full containment or if uncertain then evaluate as medium. Typical engineered systems include leachate collection systems and low permeability liners.

Primary sources of information: Site operational records.

SCORE 
b. Thickness of confining layer over aquifer(s) of concern: The thickness of a confining layer (e.g. clay, shale, etc.) between contaminants and any aquifers of concern will affect the attenuation of contaminants and hence the quantity and quality of contaminants reaching the aquifers.

Action: (1) Document local geological conditions relative to the nature and thickness of the confining layer between contaminants and aquifers. (2) Identify water-bearing zones used for water supply.

\begin{tabular}{|c|c|c|c|}
\hline \multicolumn{4}{|c|}{$\begin{array}{l}\text { EVALUATION FACTORS FOR THICKNESS OF CONFINING LAYER OVER AQUIFER(S) OF } \\
\text { CONCERN }{ }^{1}\end{array}$} \\
\hline EVALUATION FACTOR & $\begin{array}{l}\text { SCORING } \\
\text { GUIDELINE }\end{array}$ & COMMENTS & $\begin{array}{l}\text { UNCERTAINTY } \\
\qquad(\mathrm{H}, \mathrm{M}, \mathrm{L})\end{array}$ \\
\hline $\begin{array}{l}\text { Confining layer thickness } \\
3 \mathrm{~m} \text { or less }\end{array}$ & 1.5 & & \\
\hline $\begin{array}{l}\text { Confining layer thickness } \\
3 \text { to } 10 \mathrm{~m}\end{array}$ & 1 & & \\
\hline $\begin{array}{l}\text { Confining layer thickness } \\
>10 \mathrm{~m}\end{array}$ & 0 & & \\
\hline
\end{tabular}

Method of Evaluation: Measure or estimate thickness of any confining layer (e.g. clay, shale, etc.) over all aquifers of concern from existing well records or from a general knowledge of local conditions. If possible, an estimate of the continuity of the confining layer should be made from borehole well record information.

Note: an aquifer is defined as a geologic material that will yield groundwater in useable quantities.

Primary sources of information: Historical geologic maps, well records, government hydrogeologist or local consultants.

SCORE 
c. Hydraulic conductivity of the confining layer: The rate at which contaminants migrate through the confining layer (hydraulic conductivity) will affect attenuation and the contaminant loading to the aquifers.

Action: Document or estimate hydraulic conductivity for any confining layer identified between the contaminants and aquifers.

\begin{tabular}{|c|c|c|c|}
\hline \multicolumn{4}{|c|}{ EVALUATION FACTORS FOR HYDRAULIC CONDUCTIVITY OF THE CONFINING LAYER ${ }^{1}$} \\
\hline EVALUATION FACTOR & $\begin{array}{l}\text { SCORING } \\
\text { GUIDELINE }\end{array}$ & COMMENTS & $\begin{array}{c}\text { UNCERTAINTY } \\
(\mathrm{H}, \mathrm{M}, \mathrm{L})\end{array}$ \\
\hline $\begin{array}{l}\mathrm{HC}>10^{-4} \mathrm{~cm} / \mathrm{sec} \\
(\mathrm{High})\end{array}$ & 1.5 & & \\
\hline $\begin{array}{l}\mathrm{HC}=10^{-4} \text { to } 10^{-6} \mathrm{~cm} / \mathrm{sec} \\
\text { (Medium) }\end{array}$ & 1 & & \\
\hline $\begin{array}{l}\mathrm{HC}<10^{-6} \mathrm{~cm} / \mathrm{sec} \\
(\text { Low })\end{array}$ & 0.5 & & \\
\hline
\end{tabular}

Method of Evaluation: Determine the nature of geologic materials and estimate hydraulic conductivity from published material.

Low Hydraulic Conductivity: Clays, granite, shales.

Medium Hydraulic Conductivity: Silts.

High Hydraulic Conductivity: Sand, gravel, and limestone.

Primary sources of Information: Well records to determine the constitution of the confining layers. Groundwater texts or handbooks (e.g. Freeze and Cherry, 1979) to determine hydraulic conductivity.

SCORE 
d. Annual Rainfall: The quantity of rainfall affects the quantity of leachate produced. High precipitation increases the potential for the leaching of contaminants into the groundwater.

Action: Document annual rainfall data at or near the site.

\begin{tabular}{||l|c|c|c|}
\hline \hline EVALUATION FACTORS FOR ANNUAL RAINFALL & COMMENTS \\
\hline $\begin{array}{l}\text { EVALUATION } \\
\text { FACTOR }\end{array}$ & $\begin{array}{l}\text { SCORING } \\
\text { GUIDELINE }\end{array}$ & $\begin{array}{c}\text { UNCERTAINTY } \\
(\mathrm{H}, \mathrm{M}, \mathrm{L})\end{array}$ \\
\hline$R>1000 \mathrm{~mm}$ & 1 & & \\
\hline$R \approx 600 \mathrm{~mm}$ & 0.6 & & \\
\hline$R \approx 400 \mathrm{~mm}$ & 0.4 & & \\
\hline$R \approx 200 \mathrm{~mm}$ & 0.2 & & \\
\hline 1 & & \\
\hline
\end{tabular}

Method of evaluation: Obtain precipitation records for relevant areas. Use 30-year average rainfall for evaluation purposes. Divide rainfall by 1000 and round to nearest tenth (e.g. $667 \mathrm{~mm}$ 0.7 score).

Primary sources of information: Hydrological Atlas, U.S. Weather Bureau Statistics. 
e. Hydraulic conductivity of aquifer(s) of concern: Aquifers with high hydraulic conductivity can transport contaminants at high velocity over great distances, e.g. solution limestones, highly fractured rocks, or gravel deposits.

Action: Estimate hydraulic conductivity of relevant aquifer(s).

\begin{tabular}{||l|c|c|c||}
\hline \hline \multicolumn{3}{||l|}{ EVALUATION FACTORS FOR HYDRAULIC CONDUCTIVITY OF THE AQUIFER(S) } \\
\hline $\begin{array}{l}\text { EVALUATION } \\
\text { FACTOR }\end{array}$ & $\begin{array}{l}\text { SCORING } \\
\text { GUIDELINE }\end{array}$ & $\begin{array}{c}\text { COMMENTS } \\
\text { (H, M, L) }\end{array}$ \\
\hline $\mathrm{HC}>10^{-2} \mathrm{~cm} / \mathrm{sec}$ & 3 & & \\
\cline { 1 - 2 } $\begin{array}{l}\mathrm{HC}=10^{-2} \text { to } 10^{-4} \\
\mathrm{Cm} / \mathrm{sec}\end{array}$ & 1.5 & & \\
\cline { 1 - 1 }$<10^{-4} \mathrm{~cm} / \mathrm{sec}$ & 0.5 & & \\
\hline
\end{tabular}

Method of Evaluation: Determine the nature of geologic materials and estimate hydraulic conductivity of all aquifers of concern from published material.

Primary sources of information: Well logs, groundwater texts or handbooks (e.g. Freeze and Cherry, 1979).

SCORE 
3. Special Considerations for Groundwater Exposure Pathways: Conditions or situations relating to exposure pathways that are not represented by the evaluation factors may be considered. These "special considerations" factors are intended to allow the user sufficient flexibility to address unique aspects of contaminant exposure pathways or to emphasize important concerns relating to exposure pathways. These special considerations are intended to be used as an exception rather than a rule.

Action: Document any other important ground water issues not addressed above.

Score guidelines: -4 to +4

Primary sources of information: Technical judgment of the evaluator. Input from other interested parties.

SCORE 


\section{B. Surface Water}

1. Observed or measured contamination of water/effluent discharged from the site:

Contamination of surface waters should be avoided or prevented.

Action: Document information on surface water contamination originating from the site.

\begin{tabular}{|l|c|c|c|}
\hline \hline \multicolumn{4}{|l|}{$\begin{array}{l}\text { EVALUATION FACTORS FOR OBSERVED OR MEASURED CONTAMINATION OF } \\
\text { WATER/EFFLUENT DISCHARGED FROM THE SITE }\end{array}$} \\
\hline EVALUATION FACTOR & $\begin{array}{l}\text { SCORING } \\
\text { GUIDELINE }\end{array}$ & COMMENTS & $\begin{array}{c}\text { UNCERTAINTY } \\
\text { (H, M, L) }\end{array}$ \\
\hline $\begin{array}{l}\text { Known or strongly suspected to } \\
\text { exceed water quality standards }\end{array}$ & 11 & & \\
\cline { 1 - 2 } $\begin{array}{l}\text { Known or strongly suspected to } \\
\text { be between } 1 \text { to } 2 \text { x water } \\
\text { quality standards }\end{array}$ & 6 & & \\
\hline Meets water quality standards & 0 & & \\
\hline
\end{tabular}

Method of evaluation: Collect all available information on quality of surface waters near the site. Evaluate data against water quality standards (select appropriate guidelines based on local water use - e.g. recreational, irrigation, freshwater aquatic life, etc.).

Primary sources of information: Relevant federal and state water quality regulations and guidelines. Site discharge permits. Site and other local water monitoring data.

SCORE 


\section{Potential for surface water contamination}

a. Surface containment: The level and type of engineered containment will affect the potential for contaminants to be released tc surface water. Berms, for example, may be used for surface containment around reserve pits at petroleum E\&P sites.

Action: Review and document engineered or natural systems protecting surface water at the site.

\begin{tabular}{|l|c|c|c||}
\hline \hline \multicolumn{2}{||l|}{ EVALUATION FACTORS FOR SURFACIE CONTAINMENT' } \\
\hline $\begin{array}{l}\text { EVALUATION } \\
\text { FACTOR }\end{array}$ & $\begin{array}{c}\text { SCORING } \\
\text { GUIDELINE }\end{array}$ & $\begin{array}{c}\text { COMMENTS } \\
\text { (H, M, L) }\end{array}$ \\
\hline No containment & 5 & & \\
\hline $\begin{array}{l}\text { Partial } \\
\text { containment }\end{array}$ & 3 & & \\
\hline Full containment & 0.5 & & \\
\hline 'Adapted from Canadian National Classification System for Contaminated Sites \\
\hline
\end{tabular}

Method of Evaluation: Review existing engineered systems and relate these structures to site conditions and proximity to surface water and determine if full containment is achieved (e.g. evaluate low if there is full containment such as capping, berms, dikes, evaluate medium if there is partial containment such as natural barriers, trees, ditches, sedimentation ponds; evaluate high if there are no intervening barriers between the site and nearby surface waters.

Review available mapping and survey data to determine distance to the nearest surface water bodies.

Primary sources of information: Site inspection reports, air photos, etc.

\section{SCORE}


b. Distance to perennial surface water: The distance to surface water will affect the probability of contaminants reaching the watercourse.

Action: Estimate distance from site to nearest stream or other water body.

\begin{tabular}{|l|c|c|c||}
\hline \hline \multicolumn{2}{|||}{ EVALUATION FACTORS FOR DISTANCE TO PERENNIAL SURFACE WATER } \\
\hline $\begin{array}{l}\text { EVALUATION } \\
\text { FACTOR }\end{array}$ & $\begin{array}{c}\text { SCORING } \\
\text { GUIDELINE }\end{array}$ & COMMENTS & $\begin{array}{c}\text { UNCERTAINTY } \\
\text { (H, M, L) }\end{array}$ \\
\hline D $<100 \mathrm{~m}$ & 3 & & \\
\hline D $=100$ to $300 \mathrm{~m}$ & 2 & & \\
\hline D $>300 \mathrm{~m}$ & 0.5 & & \\
\hline 'Adapted from Canadian National Classification System for Contaminated Sites \\
\hline
\end{tabular}

Method of Evaluation: Estimate the distance from contaminants to any perennial source of surface water.

Primary sources of information: Site maps, U.S.G.S. topographic maps, direct measurements.

SCORE 
c. Topography: Water can run off with greater ease from elevated sites on steep slopes. The more rapid the run off, the greater the possibility of surface water contamination.

Action: Document terrain conditions at the site, and the position of contaminants relative to the ground surface (i.e. above ground or buried).

\begin{tabular}{|l|c|c|c||}
\hline \hline EVALUATION FACTORS FOR TOPOGRAPHY' & $\begin{array}{c}\text { UNCERTAINTY } \\
\text { (H, M, L) }\end{array}$ \\
\hline $\begin{array}{l}\text { EVALUATION } \\
\text { FACTOR }\end{array}$ & $\begin{array}{l}\text { SCORING } \\
\text { GUIDELINE }\end{array}$ & COMMENTS & \\
\hline $\begin{array}{l}\text { Contaminants above } \\
\text { ground level and slope } \\
\text { is steep }\end{array}$ & 1.5 & & \\
\hline $\begin{array}{l}\text { Contaminants at or } \\
\text { below ground level and } \\
\text { slope is steep }\end{array}$ & 1.2 & \\
\hline $\begin{array}{l}\text { Contaminants above } \\
\text { ground level and slope } \\
\text { is shallow }\end{array}$ & 0.8 & \\
\hline $\begin{array}{l}\text { Contaminants at or } \\
\text { below ground level and } \\
\text { slope is shallow }\end{array}$ & 0 & \\
\hline \begin{tabular}{l} 
1Adapted from Canadian National Classific:ation System for Contaminated Sites \\
\hline
\end{tabular}
\end{tabular}

Method of Evaluation: Review engineering documents and/or topographic maps to assess the general topography of the site and the slope of surrounding terrain. (note - steep slope: $>50 \%$; Shallow slope: $<5 \%$ ).

Primary sources of information: Site engineering documents, topographic maps.

SCORE 
d. Run-off potential: Run-off transports contaminants into water bodies. Surface water runoff is a function of precipitation and the rate of infiltration, with less permeable soils allowing greater potential for run-off.

Action: Document geological and rainfall conditions.

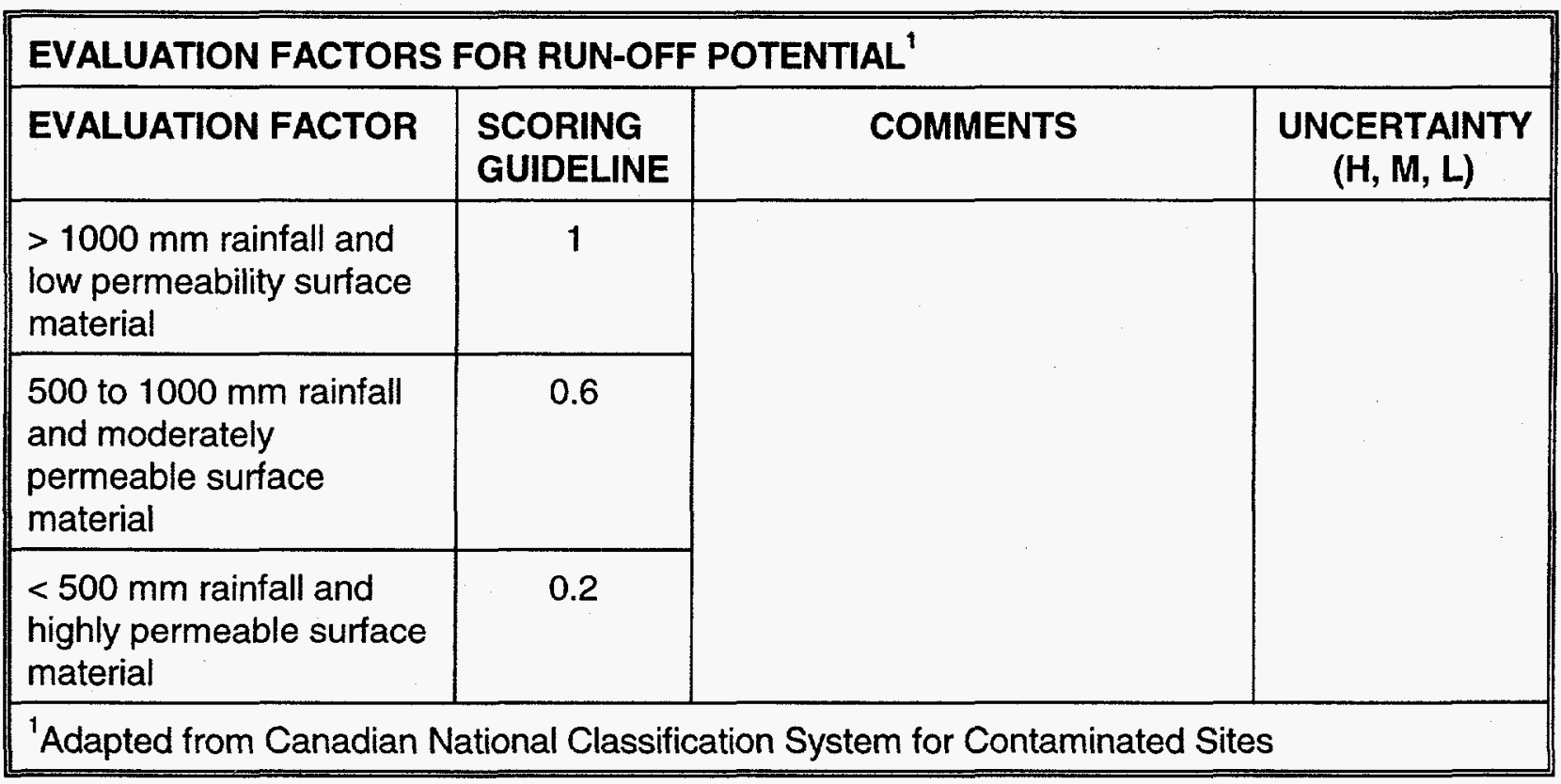

Method of evaluation: U.S. Weather Bureau statistics on precipitation records fro relevant areas. Use 30-year average precipitation for evaluation purposes. Determine factor score using "Run-off Potential Nomograph" figure (Appendix D of the NCS User's Guide).

Primary sources of information: Hydrological Atlas, U.S. Weather Bureau statistics, site or local soil permeability data.

SCORE 
e. Flood potential: The potential for large quantities and concentrations of contaminants to be released to surface water courses over a short period of time will be affected by the flood potential of a water course near the site.

Action: Document or estimate flood frequency of nearby water courses or water bodies.

\begin{tabular}{|c|c|c|c|}
\hline \multicolumn{4}{|c|}{ EVALUATION FACTORS FOR FLOOD POTENTIAL ${ }^{1}$} \\
\hline $\begin{array}{l}\text { EVALUATION } \\
\text { FACTOR }\end{array}$ & $\begin{array}{l}\text { SCORING } \\
\text { GUIDELINE }\end{array}$ & COMMENTS & $\begin{array}{c}\text { UNCERTAINTY } \\
(\mathbf{H}, \mathbf{M}, \mathbf{L})\end{array}$ \\
\hline 1 in 2 years & 0.5 & & \\
\hline 1 in 10 years & 0.3 & & \\
\hline $\begin{array}{l}1 \text { in } 50 \text { years } \\
\text { permeable } \\
\text { surface material }\end{array}$ & 0.1 & & \\
\hline
\end{tabular}

Method of evaluation: Review published clata such as flood plain mapping or flood potential (e.g. spring or mountain run-off), and USGS records to evaluate flood potential of nearby water courses both up and down gradient. Rate zero if the site is not located within a flood plain.

Primary sources of information: Established flood plain guidelines and maps; state soil conservation maps.

SCORE 
3. Special Considerations for Surface Water Exposure Pathways: Conditions or situations relating to surface water exposure pathways that are not represented by the evaluation factors may be considered. These "special considerations" factors are intended to allow the user sufficient flexibility to address unique aspects of contaminant exposure pathways or to emphasize important concerns relating to exposure pathways. These special considerations are intended to be used as an exception rather than a rule.

Action: Document any other important surface water considerations not addressed above.

Score guidelines: -4 to +4

Primary sources of information: Technical judgment of the evaluator. Input from other interested parties.

SCORE 


\section{Direct Contact}

1. Known contamination of media off-site: Known contamination off-site is an important consideration for determining impact of contaminants. The presence of contamination off-site indicates that migration has occurred, and rnay be continuing to occur.

Action: Document any off-site contamination that has been known to have occurred during the operation of the site. Media of concern include soil, sediment, and air (water has been considered separately). Document unconfirmed reports of off-site contamination due to contact with contaminated soil, dust, air, etc.

\begin{tabular}{|l|c|c|c||}
\hline \hline \multicolumn{2}{||}{ EVALUATION FACTORS FOR KNOWN CONTAMINATION OF MEDIA OFF-SITE } \\
\hline EVALUATION FACTOR & $\begin{array}{c}\text { SCORING } \\
\text { GUIDELINE }\end{array}$ & COMMENTS & $\begin{array}{c}\text { UNCERTAINTY } \\
\text { (H, M, L) }\end{array}$ \\
\hline $\begin{array}{l}\text { Known contamination of soil, } \\
\text { sediment, or air off-site due to } \\
\text { contact with contaminated } \\
\text { soil, dust, air, etc. (vector } \\
\text { transported should also be } \\
\text { considered) }\end{array}$ & 11 & & \\
\hline $\begin{array}{l}\text { Strongly suspected } \\
\text { contamination of media off- } \\
\text { site }\end{array}$ & 6 & \\
\hline $\begin{array}{l}\text { No contamination of media } \\
\text { off-site }\end{array}$ & 0 & \\
\hline \begin{tabular}{l} 
1Adapted from Canadian National Classification System for Contaminated Sites \\
\hline
\end{tabular}
\end{tabular}

Method of evaluation: Record known or measured contamination of soil, sediment, or air offsite. Note any presence of soil gas, such as methane, associated with the site.

Primary sources of information: Site monitoring data, local and regional air pollution monitoring programs, etc. 


\section{Potential for direct human and/or animal contact:}

a. Airborne emissions (gases, vapors, dust, etc.): If air emissions are evident off-site, there is a potential hazard for direct contamination of neighboring biota and/or resources.

Action: Document incidents or complaints about fumes, gases, dust, odors, etc.

\begin{tabular}{|l|c|c|c||}
\hline \hline EVALUATION FACTORS FOR AIRBORNE EMISSIONS & \\
\hline EVALUATION FACTOR & $\begin{array}{c}\text { SCORING } \\
\text { GUIDELINE }\end{array}$ & COMMENTS & $\begin{array}{c}\text { UNCERTAINTY } \\
\text { (H, M, L) }\end{array}$ \\
\hline $\begin{array}{l}\text { Known or suspected } \\
\text { airborne emissions } \\
\text { impacting on neighboring } \\
\text { properties }\end{array}$ & 5 & & \\
\cline { 1 - 2 } $\begin{array}{l}\text { Airborne emissions } \\
\text { generally restricted to site }\end{array}$ & 3 & & \\
\cline { 1 - 3 } No airborne emissions & 0 & & \\
\hline
\end{tabular}

Method of evaluation: Review available site information to determine if there have been complaints off-site (due to vapors, gas, dust, etc.). Reports for these problems are not likely available for most abandoned sites. Review regulatory site selection reports. If airborne emissions are known to be impacting neighboring properties, and possibly endangering the public, some immediate action (including characterization of emissions) should be initiated to curtail hazardous emissions or otherwise reduce or eliminate exposure.

Primary sources of information: Site inspection reports, etc.

SCORE 
b. Accessibility of Site (ability to contact materials): The greater the accessibility to a site and to contaminants, the greater the chance for contamination of human and animal life by direct contact. Petroleum E\&P sites are often found within agricultural operations.

Action: Review and document avenues of site access by humans and animals. Assess any barriers to human or animal use. Determine whether the site is used by humans and animals, or if such use is expected to increase in the future.

\begin{tabular}{|c|c|c|c|}
\hline \multicolumn{4}{|c|}{ EVALUATION FACTORS FOR ACCESSIBILITY OF SITE } \\
\hline EVALUATION FACTOR & $\begin{array}{l}\text { SCORING } \\
\text { GUIDELINE }\end{array}$ & COMMENTS & $\begin{array}{c}\text { UNCERTAINTY } \\
(\mathrm{H}, \mathrm{M}, \mathrm{L})\end{array}$ \\
\hline $\begin{array}{l}\text { Limited or no barriers to } \\
\text { prevent site access; } \\
\text { contaminants not covered }\end{array}$ & 4 & & \\
\hline $\begin{array}{l}\text { Moderate accessibility or } \\
\text { intervening barriers; } \\
\text { contaminants are covered. }\end{array}$ & 3 & & \\
\hline $\begin{array}{l}\text { Controlled access or } \\
\text { remote location and } \\
\text { contaminants are covered. }\end{array}$ & 0 & & \\
\hline
\end{tabular}

Method of evaluation: Review location and engineering of the site and determine if there are intervening barriers between the site and humans or animals. A low rating should be assigned to a (covered) site surrounded by a locked chain link fence or in a remote location, whereas a high score should be assigned to a site that has no cover, fence, natural barriers, or buffer.

\section{Sources of information:}

SCORE 
c. Hazardous soil gas migration: The migration of methane and other gases may occur from petroleum E\&P sites.

Action: Review the potential for hazardous soil gas production and migration from the site.

\begin{tabular}{|c|c|c|c|}
\hline \multicolumn{4}{|c|}{ EVALUATION FACTORS FOR MIGRATION OF HAZARDOUS SOIL GAS ${ }^{1}$} \\
\hline EVALUATION FACTOR & $\begin{array}{l}\text { SCORING } \\
\text { GUIDELINE }\end{array}$ & COMMENTS & $\begin{array}{c}\text { UNCERTAINTY } \\
(\mathrm{H}, \mathrm{M}, \mathrm{L})\end{array}$ \\
\hline $\begin{array}{l}\text { Methane or other } \\
\text { hazardous soil gases are } \\
\text { present or may be formed, } \\
\text { and soil permeability is high }\end{array}$ & 2 & & \\
\hline $\begin{array}{l}\text { Methane or other } \\
\text { hazardous soil gases are } \\
\text { present or may be formed, } \\
\text { but soil permeability is low. }\end{array}$ & 1 & & \\
\hline $\begin{array}{l}\text { Methane or other } \\
\text { hazardous soil gases are } \\
\text { not present (except where } \\
\text { adequately contained). }\end{array}$ & 0 & & \\
\hline
\end{tabular}

Method of evaluation: Consider presence of methane or organic material which may putrify on site. Also consider the depth to water table, soil hydraulic conductivity, vegetative stress, reports of odors, etc.

Primary sources of information: Site operational records. Reports of odors, etc.

SCORE 
3. Special Considerations for Direct Human Contact: Conditions or situations relating to the direct contact of humans with contaminants that are not represented by the evaluation factors may be considered. These "special considerations" factors are intended to allow the user sufficient flexibility to address unique aspects of direct contact or to emphasize important concerns relating to direct contact. These special considerations are intended to be used as an exception rather than a rule.

Action: Document any other conditions whereby humans/animals could contact contamination:

Score guidelines: -4 to +4

Primary sources of information: Technical judgment of the evaluator. Input from other interested parties.

SCORE 
2.2.1.3 RECEPTORS - The third group of characteristics pertains to the potential receptors for contaminants. These represent both human and environmental/ecological endpoints.

\section{A. Human and Animal Uses:}

1. Known adverse impact on humans or domestic animals as a result of the contaminated site: Contamination from a site that causes a measurable impact on humans is a great concern.

Action: Record known or suspected adverse effects on humans or domestic animals from site contamination.

\begin{tabular}{|c|c|c|c|}
\hline \multicolumn{4}{|c|}{$\begin{array}{l}\text { EVALUATION FACTORS FOR KNOWN ADVERSE IMPACT ON HUMANS OR DOMESTIC } \\
\text { ANIMALS }\end{array}$} \\
\hline EVALUATION FACTOR & $\begin{array}{l}\text { SCORING } \\
\text { GUIDELINE }\end{array}$ & COMMENTS & $\begin{array}{l}\text { UNCERTAINTY } \\
\qquad(\mathrm{H}, \mathrm{M}, \mathrm{L})\end{array}$ \\
\hline $\begin{array}{l}\text { Known adverse effect on } \\
\text { humans or domestic } \\
\text { animals }\end{array}$ & 18 & & \\
\hline $\begin{array}{l}\text { Strongly suspected } \\
\text { adverse effect on humans } \\
\text { or domestic animals. }\end{array}$ & 11 & & \\
\hline
\end{tabular}

Method of evaluation: Review and evaluate reports of impact(s) from site contamination (e.g. increased heavy metal levels measured in blood of nearby residents as a result of site contamination). An adverse effect is considered to be any one or more of the following: (1) impairment of the quality of the natural environment for any use that can be made of it; (2) injury or damage to property or to plant or animal life; (3) harm or material discomfort to any person; (4) impairment of the safety of any person; (5) rendering any property or plant or animal life unfit for use by humans; (6) loss of enjoyment of normal use of property; and (7) interference with the normal conduct of business.

Primary sources of information: Historical site record. Records of formal and informal complaints against the site.

SCORE 
2. Potential for impact on humans or animals:

a. Drinking water supply

i. Known impact on drinking water supply due to site contamination: Water used for drinking should be protected against contarnination from any site.

Action: Record known or suspected incidents of contamination of drinking water.

\begin{tabular}{|c|c|c|c|}
\hline \multicolumn{4}{|c|}{$\begin{array}{l}\text { EVALUATION FACTORS FOR KNOWN ADVERSE IMPACT TO DRINKING WATER } \\
\text { SUPPLY }\end{array}$} \\
\hline EVALUATION FACTOR & $\begin{array}{l}\text { SCORING } \\
\text { GUIDELINE }\end{array}$ & COMMENTS & $\begin{array}{l}\text { UNCERTAINTY } \\
\qquad(\mathrm{H}, \mathrm{M}, \mathrm{L})\end{array}$ \\
\hline $\begin{array}{l}\text { Known contamination of } \\
\text { drinking water supply to } \\
\text { levels above drinking } \\
\text { water standards }\end{array}$ & 9 & & \\
\hline $\begin{array}{l}\text { Strongly suspected } \\
\text { contamination of } \\
\text { drinking water supply. }\end{array}$ & 7 & & \\
\hline $\begin{array}{l}\text { Drinking water supply is } \\
\text { known not to be } \\
\text { contaminated. }\end{array}$ & 0 & & \\
\hline
\end{tabular}

Method of evaluation: Review available sile data (inspection reports, assessment documentation) to determine if drinking water (groundwater, surface water, private, commercial, or municipal supply) is known or suspected to be contaminated above Drinking Water standards or applicable State guidelines or policies. If drinking waters supply is known to be contaminated above these guidelines, some immediate action (e.g. provision of alternate drinking water supply) should be initiated to reduce or eliminate exposure.

Primary sources of information: U.S. EPA, State water quality boards, site permits, etc. 


\section{ii. Potential for impact on drinking water supply}

- Proximity to Drinking water supply. The nearer a drinking water well is to a contaminant source, the greater the potential for contamination. Well water used for irrigation/agricultural purposes should also be included as it may be used for human consumption.

Action: Identify the nearest drinking water well and measure distance from the well to the site.

\begin{tabular}{|c|c|c|c|}
\hline \multicolumn{4}{|c|}{ EVALUATION FACTORS FOR PROXIMITY TO WATER SUPPLY ${ }^{\dagger}$} \\
\hline $\begin{array}{l}\text { EVALUATION } \\
\text { FACTOR }\end{array}$ & $\begin{array}{l}\text { SCORING } \\
\text { GUIDELINE }\end{array}$ & COMMENTS & $\begin{array}{c}\text { UNCERTAINTY } \\
(\mathbf{H}, \mathbf{M}, \mathbf{L})\end{array}$ \\
\hline $\begin{array}{l}\text { Nearest drinking water } \\
\text { supply } 0 \text { to } 100 \mathrm{~m} \text { from } \\
\text { facility }\end{array}$ & 6 & & \\
\hline $\begin{array}{l}\text { Nearest drinking water } \\
\text { supply } 100 \text { to } 300 \mathrm{~m} \\
\text { from facility }\end{array}$ & 5 & & \\
\hline $\begin{array}{l}\text { Nearest drinking water } \\
\text { supply } 300 \mathrm{~m} \text { to } 1 \mathrm{~km} \\
\text { from facility }\end{array}$ & 4 & & \\
\hline $\begin{array}{l}\text { Nearest drinking water } \\
\text { supply } 1 \text { to } 5 \mathrm{~km} \text { from } \\
\text { facility }\end{array}$ & 3 & & \\
\hline
\end{tabular}

Method of evaluation: Review state base maps or aerial photos and measure the distance to the nearest resident or drinking water supply. Determine whether the water is being used as a drinking water source. Commonly rural areas use groundwater for drinking purposes. For urban sites, contact the local Public Utilities Commission to determine water source and location.

Primary sources of information: U.S. and state geological surveys. Maps. Permit information.

SCORE 
- Availability of alternate drinking water supply: This factor takes into account the availability of replacement water supplies, and is used in the technical sense as a factor to indicate the degree of urgency, rather than as a sociopolitical consideration.

Action: Document the availability of alternate sources of drinking water and ease of implementation for the nearest groundwater well.

\begin{tabular}{|c|c|c|c|}
\hline \multicolumn{4}{|c|}{$\begin{array}{l}\text { EVALUATION FACTORS FOR AVAILAB ILITY OF ALTERNATE DRINKING WATER } \\
\text { SUPPLY }{ }^{1}\end{array}$} \\
\hline EVALUATION FACTOR & $\begin{array}{c}\text { SCORING } \\
\text { GUIDELINE }\end{array}$ & COMMENTS & $\begin{array}{c}\text { UNCERTAINTY } \\
(\mathrm{H}, \mathrm{M}, \mathrm{L})\end{array}$ \\
\hline $\begin{array}{l}\text { Alternate drinking water } \\
\text { supply is not available. }\end{array}$ & 3 & & \\
\hline $\begin{array}{l}\text { Alternate drinking water } \\
\text { supply would be difficult } \\
\text { to obtain. }\end{array}$ & 2 & & \\
\hline $\begin{array}{l}\text { Alternate drinking water } \\
\text { supply is available. }\end{array}$ & 0.5 & & \\
\hline
\end{tabular}

Method of evaluation: Determine availability of alternate drinking water supply or distance to alternate source.

Primary sources of information:

SCORE 


\section{b. Other water resources}

i. Known impact on used water resource. Water resources (used for recreational purposes, commercial food preparation, livestock watering, irrigation, or other food chain uses) are known to be adversely affected as a result of site contamination. The water used for these purposes (groundwater or surface water) should be protected against contamination.

Action: Record information on water resources that are (or are potentially) affected by site contamination.

\begin{tabular}{|l|c|c|c||}
\hline \hline EVALUATION FACTORS FOR KNOWN IMPACT ON USED WATER RESOURCE \\
\hline EVALUATION FACTOR & $\begin{array}{c}\text { SCORING } \\
\text { GUIDELINE }\end{array}$ & $\begin{array}{c}\text { COMMENTS } \\
\text { (H, M, L) }\end{array}$ \\
\hline $\begin{array}{l}\text { Water resource is known } \\
\text { to be contaminated above } \\
\text { drinking water standards. }\end{array}$ & 4 & & \\
\cline { 1 - 2 } $\begin{array}{l}\text { Water resource is strongly } \\
\text { suspected to be } \\
\text { contaminated above } \\
\text { drinking water standards. }\end{array}$ & 3 & & \\
\hline $\begin{array}{l}\text { Water resource is known } \\
\text { not to be contaminated. }\end{array}$ & 0 & & \\
\hline 'Adapted from Canadian National Classification System for Contaminated Sites \\
\hline
\end{tabular}

Method of evaluation: Determine availability of alternate drinking water supply or distance to alternate source.

Primary sources of information: Safe drinking water regulations or state water quality regulations and guidance.

SCORE 
ii. Potential for impact on water resources:

- Proximity to water resources used for activities listed above: The nearer a water resource is to a site, the greater the risk of contamination.

Action: Locate and measure nearest water resource areas to the site.

\begin{tabular}{|c|c|c|c|}
\hline \multicolumn{4}{|c|}{ EVALUATION FACTORS FOR PROXIMITY TO WATER RESOURCES ${ }^{1}$} \\
\hline $\begin{array}{l}\text { EVALUATION } \\
\text { FACTOR }\end{array}$ & $\begin{array}{l}\text { SCORING } \\
\text { GUIDELINE }\end{array}$ & COMMENTS & $\begin{array}{c}\text { UNCERTAINTY } \\
(H, M, L)\end{array}$ \\
\hline 0 to $100 \mathrm{~m}$ & 2 & & \\
\hline 100 to $300 \mathrm{~m}$ & 1.5 & & \\
\hline $300 \mathrm{~m}$ to $1 \mathrm{~km}$ & 1 & & \\
\hline 1 to $5 \mathrm{~km}$ & 0.5 & & \\
\hline
\end{tabular}

Method of evaluation: Determine the distance from the site to the nearest recreational or food chain water resource use.

Primary sources of information:

SCORE 
- Use of water resources (if multiple uses, give the highest score using the following table: Potential for impact due to use of water resource is related to the type and frequency of use. Human uses are of the highest concern.

Action: Record uses of nearby water resources.

\begin{tabular}{|c|c|c|c|c|}
\hline \multicolumn{5}{|c|}{ EVALUATION FACTORS FOR USE OF WATER RESOURCES ${ }^{1}$} \\
\hline \multirow[t]{2}{*}{ WATER USE } & \multicolumn{2}{|c|}{$\begin{array}{l}\text { FREQUENCY OF USE } \\
\text { (SCORING GUIDELINE) }\end{array}$} & \multirow[t]{2}{*}{ COMMENTS } & \multirow{2}{*}{$\begin{array}{c}\text { UNCERTAINTY } \\
(\mathrm{H}, \mathrm{M}, \mathrm{L})\end{array}$} \\
\hline & FREQUENT & OCCASIONAL & & \\
\hline $\begin{array}{l}\text { Recreational } \\
\text { (swimming, fishing) }\end{array}$ & 2 & 1 & & \\
\hline $\begin{array}{l}\text { Commercial food } \\
\text { preparation }\end{array}$ & 1.5 & 0.8 & & \\
\hline Livestock watering & 1 & 0.5 & & \\
\hline Irrigation & 1 & 0.5 & & \\
\hline $\begin{array}{l}\text { Other domestic or } \\
\text { food chain uses }\end{array}$ & 0.5 & 0.3 & & \\
\hline $\begin{array}{l}\text { Not currently used } \\
\text { but likely future use }\end{array}$ & 0.5 & 0.2 & & \\
\hline
\end{tabular}

Method of evaluation: Assess water users adjacent to the site from maps and directories.

Primary sources of information:

SCORE 


\section{c. Direct human exposure}

i. Known contamination of land used by humans: Hazards associated with soil contamination are directly related to land use.

Action: Record land use type (current or proposed) and level of contamination for land known to be contaminated due to site.

\begin{tabular}{|c|c|c|c|}
\hline \multicolumn{4}{|c|}{ EVALUATION FACTORS FOR KNOWN CONTAMINATION OF LAND USED BY HUMANS ${ }^{1}$} \\
\hline EVALUATION FACTOR & $\begin{array}{l}\text { SCIDRING } \\
\text { GUIIDELINE }\end{array}$ & COMMENTS & $\begin{array}{c}\text { UNCERTAINTY } \\
(\mathrm{H}, \mathrm{M}, \mathrm{L})\end{array}$ \\
\hline $\begin{array}{l}\text { Known contamination of land used } \\
\text { for agricultural or residential/ } \\
\text { parkland/school purposes above } \\
\text { acceptable values. }\end{array}$ & 5 & & \\
\hline $\begin{array}{l}\text { Known contamination of land used } \\
\text { for commercial or industrial } \\
\text { purposes above acceptable values }\end{array}$ & 3.5 & & \\
\hline $\begin{array}{l}\text { Land known not to be } \\
\text { contaminated. }\end{array}$ & 0 & & \\
\hline
\end{tabular}

Method of evaluation: Review zoning and land use maps for lands adjacent to the site. Evaluate levels of soil contamination against EPA values for contaminated sites for agricultural lands, residential areas, parklands, commercial/ industrial sites. If soil is known to be contaminated above these levels and possibly endangering public health, some immediate action (e.g. fencing of the area, limiting public access, etc.) should be initiated to reduce or eliminate the exposure.

Primary sources of information: EPA criteria for contaminated sites.

SCORE 
ii. Potential human exposure through land use. Use of land at and surrounding site (use following table; give highest score to worst case scenario). Hazards associated with soil contamination are directly related to land use and distance of the used land from the site. Residential and agricultural land uses are of highest concern because humans are situated at these locations for longer periods.

Action: Document land sues (current and proposed) for up to $5 \mathrm{~km}$ from the site:

0 to $300 \mathrm{~m}$

$N \quad E \quad S \quad W$

$300 \mathrm{~m}$ to $1 \mathrm{~km}$

1 to $5 \mathrm{~km}$

\begin{tabular}{|l|c|c|c|c|}
\hline \hline \multirow{2}{*}{ EVALUATION FACTORS FOR POTENTIAL HUMAN EXPOSURE THROUGH LAND USE } \\
\hline LAND USE & DISTANCE FROM SITE & \multirow{2}{*}{ COMMENTS } & $\begin{array}{c}\text { UNCERTAINTY } \\
\text { (H, M, L) }\end{array}$ \\
\cline { 2 - 3 } & $\mathbf{0 - 3 0 0 \mathrm { m }}$ & $\mathbf{3 0 0 \mathrm { m } - 1 \mathrm { km }}$ & & \\
\hline Residential & 5 & 4.5 & & \\
\hline Agricultural & 5 & 4 & & \\
\hline Parkland/School & 4 & 3 & \\
\hline Commercial/ndustrial & 3 & 1 & \\
\hline 'Adapted from Canadian National Classification System for Contaminated Sites
\end{tabular}

Method of evaluation: Review zoning and land use maps over the distances indicated. If the proposed future land use is more "sensitive" than the current land use, evaluate this factor assuming the proposed future use is in place (indicate in the worksheet that future land use is the consideration). Agricultural land use is defined as uses of land where the activities are related to the productive capability of the land or facility (e.g. greenhouse) and are agricultural in nature, OR activities related to the feeding and housing of animals as livestock. Residental/Parkland land uses are defined as uses of land on which dwelling on a permanent, temporary, or seasonal basis is the activity (residential), as well as uses on which the activities are recreational in nature and require the natural or human designed capability of the land to sustain that activity (Parkland). Commercial/Industrial land uses are defined as land on which the activities are related to the buying, selling, or trading of merchandise or services (commercial), as well as land uses which are related to the production, manufacture, or storage of materials (industrial).

Primary sources of information: Chamber of Commerce. Zoning data.

SCORE 
3. Special Considerations for Contaminant Receptors: Conditions or situations relating to contaminant receptors that are not represented by the evaluation factors may be considered. These "special considerations" factors are intended to allow the user sufficient flexibility to address unique aspects associated with contaminant receptors or to emphasize important concerns relating to receptors. These special considerations are intended to be used as an exception rather than a rule.

Action: Document any other important hurnan or animal use information, including details of air contamination, if known.

Score guidelines: -4 to +4

Primary sources of information: Technical judgment of the evaluator. Input from other interested parties.

SCORE 


\section{B. Environment}

1. Known adverse impact on a sensitive environment as a result of the contaminated site. The environment should be protected against site contamination. Evidence of impact(s) shows that protection is lacking.

Action: Record any known impact(s) on any sensitive environments at or around the site.

\begin{tabular}{|c|c|c|c|}
\hline \multicolumn{4}{|c|}{$\begin{array}{l}\text { EVALUATION FACTORS FOR KNOWN ADVERSE IMPACT ON A SENSITIVE } \\
\text { ENVIRONMENT AS A RESULT OF THE CONTAMINATED SITE. }\end{array}$} \\
\hline EVALUATION FACTOR & $\begin{array}{l}\text { SCORING } \\
\text { GUIDELINE }\end{array}$ & COMMENTS & $\begin{array}{l}\text { UNCERTAINTY } \\
\qquad(\mathrm{H}, \mathrm{M}, \mathrm{L})\end{array}$ \\
\hline $\begin{array}{l}\text { Known adverse impact on sensitive } \\
\text { environment }\end{array}$ & 16 & & \\
\hline $\begin{array}{l}\text { Evidence of stress on aquatic } \\
\text { species or vegetative stress on } \\
\text { trees, crops or plant life located on } \\
\text { properties neighboring the site. }\end{array}$ & 14 & & \\
\hline $\begin{array}{l}\text { Strongly suspected adverse impact } \\
\text { on sensitive environment. }\end{array}$ & 12 & & \\
\hline
\end{tabular}

Method of evaluation: Review records for evidence of vegetative stress or impairment of any nearby sensitive environments. A sensitive environment is defined as a sensitive aquatic environment, nature preserve, habitat for endangered species, sensitive forest reserves, national parks or forests, etc. An adverse effect is considered to be any one or more of the following: (1) impairment of the quality of the natural environment for any use that can be made of it; (2) injury or damage to property or to plant or animal life: (3) harm or material discomfort to any person (4) impairment of the safety of any person; (5) rendering any property or plant or animal life unfit for use by humans; (6) loss of enjoyment of normal use of property; and (7) interference with the normal conduct of business.

Primary Sources of information:

SCORE 


\section{Potential for impact on sensitive erivironments}

a. Distance from site to nearest sensitive environment: e.g. sensitive aquatic environment, nature preserve, habitat for endangered species, sensitive forest reserves, national parks or forests, etc. It is considered that within approximately $1 \mathrm{~km}$ of the site there is immediate concern for contamination. Therefore, and environmentally sensitive area located within this area of the site will be subject to concern. It is also generally considered that any sensitive area located greater than $10 \mathrm{~km}$ from the site will not be impacted.

Action: Document location, distance, type and details of any nearby sensitive environments or habitats.

\begin{tabular}{|c|c|c|c|}
\hline \multicolumn{4}{|c|}{ EVALUATION FACTORS FOR DISTANCE TO NEAREST SENSITIVE ENVIRONMENT ${ }^{1}$} \\
\hline $\begin{array}{l}\text { EVALUATION } \\
\text { FACTOR }\end{array}$ & $\begin{array}{l}\text { SCORING } \\
\text { GUIDELINE }\end{array}$ & COMMENTS & $\begin{array}{l}\text { UNCERTAINTY } \\
(\mathrm{H}, \mathrm{M}, \mathrm{L})\end{array}$ \\
\hline 0 to $500 \mathrm{~m}$ & 10 & & \\
\hline $500 \mathrm{~m}$ to $2 \mathrm{~km}$ & 6 & & \\
\hline 2 to $5 \mathrm{~km}$ & 2 & & \\
\hline 5 to $10 \mathrm{~km}$ & $<0.5$ & & \\
\hline
\end{tabular}

Method of evaluation: Review available mapping and literature. Identify state and federally designated environmentally sensitive areas.

Primary sources of information: Relevarit maps.

SCORE 
b. Groundwater - distance to important or susceptible groundwater resource(s). The closer a site is to a discharge or recharge are, the greater the potential for contamination of a groundwater or surface water resource.

Action: Measure distance to major recharge or discharge area.

\begin{tabular}{|c|c|c|c|}
\hline \multicolumn{4}{|c|}{$\begin{array}{l}\text { EVALUATION FACTORS FOR DISTANCE TO IMPORTANT OR SUSCEPTIBLE } \\
\text { GROUNDWATER RESOURCE(S) }{ }^{1}\end{array}$} \\
\hline $\begin{array}{l}\text { EVALUATION } \\
\text { FACTOR }\end{array}$ & $\begin{array}{l}\text { SCORING } \\
\text { GUIDELINE }\end{array}$ & COMMENTS & $\begin{array}{l}\text { UNCERTAINTY } \\
\qquad(\mathrm{H}, \mathrm{M}, \mathrm{L})\end{array}$ \\
\hline$D=0$ to $500 \mathrm{~m}$ & 6 & & \\
\hline$D=500 \mathrm{~m}$ to $2 \mathrm{~km}$ & 4 & & \\
\hline$D=2$ to $5 \mathrm{~km}$ & 2 & & \\
\hline$D=5$ to $10 \mathrm{~km}$ & 1 & & \\
\hline${ }^{1}$ Adapted from $\mathrm{Ca}$ & Alion & tom tor & \\
\hline
\end{tabular}

Method of evaluation: Review groundwater contour maps, if available, and other available reports. Otherwise, use established hydrogeologic principles.

Primary sources of information: Local groundwater maps, etc.

SCORE 
3. Special Considerations for the General Environment: Conditions or situations relating to the general environment that are not represented by the evaluation factors may be considered. These "special considerations" factors are intended to allow the user sufficient flexibility to address unique aspects associated with the general environment or to emphasize important concerns relating to the environment. These special considerations are intended to be used as an exception rather than a rule.

Action: Document any other important impacts on the environment not addressed above

Score guidelines: -4 to +4

Primary sources of information: Technical judgment of the evaluator. Input from other interested parties.

SCORE 
2.2.1.4 PHYSICAL DISTURBANCE - Petroleum E\&P sites may also be subject to physical disturbance factors as toxic contamination. The need for remediating physical damage to the environment is related to the total amount of area disturbed at the site, and to the type and degree of the disturbance involved. Physical disturbance of E\&P sites can be associated with site operations and infrastructure, waste disposal, oil spills, and other factors.

A. Physical disturbance from operations and infrastructure: Ideally, this information should be provided in terms of the total area disturbed. In many cases, however, this information will not be available. For example, information may be lacking for abandoned E\&P sites, at which estimates of the area contaminated should be used.

1. Disturbance associated with E\&P infrastructure: Roads, pipelines, drill pads, and other infrastructure associated with petroleum E\&P sites cannot be constructed without causing physical disturbance to the surrounding landscape. This evaluation factor deals with the immediate area of infrastructure. Remediation of these areas is complicated by the fact that the infrastructure must first be removed.

Action: Estimate the total area of the site that has been disturbed by the construction of site infrastructure. This includes roads, pipelines, drill pads, buildings, etc.

\begin{tabular}{|l|c|c|c||}
\hline \hline EVALUATION FACTORS FOR AREA COVERED BY INFRASTRUCTURE \\
\hline EVALUATION FACTOR & $\begin{array}{c}\text { SCORING } \\
\text { GUIDELINE }\end{array}$ & COMMENTS & $\begin{array}{c}\text { UNCERTAINTY } \\
(\mathbf{H}, \mathrm{M}, \mathrm{L})\end{array}$ \\
\hline Area disturbed > 10 ha & 10 & & \\
\hline Area disturbed 2 to 10 ha & 6 & & \\
\hline Area disturbed <2 ha & 2 & & \\
\hline
\end{tabular}

Method of evaluation: Use operational records and aerial photographs to estimate the total area covered by site infrastructure.

Primary sources of information: Site operational records, aerial photographs, and site surveys may be used to provide the information necessary for the area estimations. Direct measurement of infrastructure may be done at many sites.

SCORE 
2. Removal of vegetation and/or soil: The removal of vegetation and soil can result in a variety of environmental problems, including disruption of habitat and sedimentation of streams. Estimate total area where vegetation has been removed

a. Total area of disturbed vegetation and soil:

Action: Estimate the total area of the site where vegetation and/or has been removed. This estimate should exclude any area included in the infrastructure estimate (item 1 above).

\begin{tabular}{||l|c|c|c||}
\hline \hline EVALUATION FACTORS FOR AREA OF VEGETATION/SOIL DISTURBANCE \\
\hline EVALUATION FACTOR & $\begin{array}{c}\text { SCORING } \\
\text { GUIDELINE }\end{array}$ & COMMENTS & $\begin{array}{c}\text { UNCERTAINTY } \\
\text { (H, M, L) }\end{array}$ \\
\hline Area disturbed > 10 ha & 10 & & \\
\hline Area disturbed 2 to 10 ha & 6 & & \\
\hline Area disturbed < 2 ha & 2 & & \\
\hline
\end{tabular}

Method of evaluation: Use operational records and aerial photographs to estimate the total area covered of vegetation/soil disturbance.

Primary sources of information: Site operational records, aerial photographs, and site surveys may be used to provide the information necessary for the area estimations. Direct measurement of infrastructure may be done at many sites. 


\section{b. Depth of soil disturbance:}

Action: Determine the effective depth to which the soil is disturbed (i.e. vegetation only via fire or defoliant; soil compacted; organic layer removed; all topsoil removed).

\begin{tabular}{|c|c|c|c|}
\hline \multicolumn{4}{|c|}{ EVALUATION FACTORS FOR DEPTH OF SOIL DISTURBANCE } \\
\hline EVALUATION FACTOR & $\begin{array}{l}\text { SCORING } \\
\text { GUIDELINE }\end{array}$ & COMMENTS & $\begin{array}{c}\text { UNCERTAINTY } \\
(H, M, L)\end{array}$ \\
\hline $\begin{array}{l}\text { Soil removed to beneath } \\
\text { the organic layer }\end{array}$ & 10 & & \\
\hline $\begin{array}{l}\text { Surface (organic layer) } \\
\text { soil removed }\end{array}$ & 7 & & . \\
\hline $\begin{array}{l}\text { Soil compacted, not } \\
\text { removed }\end{array}$ & 5 & & \\
\hline $\begin{array}{l}\text { Removal of vegetation } \\
\text { only (no soil removed) }\end{array}$ & 2 & & \\
\hline
\end{tabular}

Method of evaluation:

Primary sources of information:

SCORE 
c. Critical habitat: The need for remediation may be higher if recognized critical habitats are found in the vicinity of the site.

Action: Evaluate the presence of critical habitat as defined by the U.S. Fish and Wildlife Service.

\begin{tabular}{|l|c|c|c||}
\hline \multicolumn{2}{|l||}{ EVALUATION FACTORS FOR CRITICAL HABITAT LOST OR AT RISK } \\
\hline $\begin{array}{l}\text { EVALUATION } \\
\text { FACTOR }\end{array}$ & $\begin{array}{c}\text { SCORING } \\
\text { GUIDELINE }\end{array}$ & COMMENTS & $\begin{array}{c}\text { UNCERTAINTY } \\
\text { (H, M, L) }\end{array}$ \\
\hline $\begin{array}{l}\text { Critical habitat found on } \\
\text { site }\end{array}$ & 6 & & \\
\hline $\begin{array}{l}\text { Critical habitat within 1 } \\
\text { km of site }\end{array}$ & 3 & & \\
\hline $\begin{array}{l}\text { Critical habitat between } \\
1 \text { and } 5 \text { km from site }\end{array}$ & 1 & & \\
\hline $\begin{array}{l}\text { No critical habitat within } \\
5 \mathrm{~km} \text { of site }\end{array}$ & 0 & & \\
\hline
\end{tabular}

Method of evaluation: Determine the distance from the site to the nearest recognized critical habitat.

Primary sources of information: U.S. Fish and Wildlife Service, state fish and game agencies.

SCORE 
d. Presence of exotic invader species: In some areas of the country, removal of vegetation can result in the invasion and establishment of exotic weed species. In arid and semiarid areas of the western U.S., for example, disturbed soils are often colonized by cheat grass (Bromus tectorum) and/or Russian thistle (Salsola australis). If remediation is to include the restoration of native plant communities, the presence of significant invaders must be evaluated.

Action: Evaluate the potential for invasion of disturbed areas by noxious exotic invader plant species.

\begin{tabular}{|l|c|c|c|}
\hline \multicolumn{2}{|l|}{ EVALUATION FACTORS FOR PRESENCE OF EXOTIC INVADER SPECIES } \\
\hline $\begin{array}{l}\text { EVALUATION } \\
\text { FACTOR }\end{array}$ & $\begin{array}{l}\text { SCORING } \\
\text { GUIDELINE }\end{array}$ & COMMENTS & $\begin{array}{c}\text { UNCERTAINTY } \\
\text { (H, M, L) }\end{array}$ \\
\hline $\begin{array}{l}\text { Noxious exotic invader } \\
\text { species prevalent in } \\
\text { disturbed areas }\end{array}$ & 2 & & \\
\hline $\begin{array}{l}\text { Noxious exotic invader } \\
\text { species present, but } \\
\text { not prevalent }\end{array}$ & 1 & & \\
\hline $\begin{array}{l}\text { No noxious exotic } \\
\text { invader species known }\end{array}$ & 0 & & \\
\hline
\end{tabular}

Method of evaluation: Determine the presence of noxious exotic invader plant species in the area, and the potential for the establishment of these species due to site operations.

Primary sources of information: Plant surveys, permits, State extension offices, Universities.

\section{SCORE}


3. Sedimentation of streams: Disturbance of the vegetation and soil can result in increased erosion, leading in turn to increased sedimentation in streams. Simple techniques such as the use of a Secchi disk to measure transparency can be used to provide an indication of relative sediment load in surface waters.

Action: Evaluate streams draining the site for increased sediment load.

\begin{tabular}{|l|c|c|c||}
\hline \multicolumn{2}{||c|}{ EVALUATION FACTORS FOR INCREASED SEDIMENT LOAD IN STREAMS } \\
\hline EVALUATION FACTOR & $\begin{array}{l}\text { SCORING } \\
\text { GUIDELINE }\end{array}$ & COMMENTS & $\begin{array}{l}\text { UNCERTAINTY } \\
\text { (H, M, L) }\end{array}$ \\
\hline $\begin{array}{l}\text { Downstream sediment } \\
\text { load increased by }>50 \%\end{array}$ & 8 & & \\
\hline $\begin{array}{l}\text { Downstream sediment } \\
\text { load increased by }<50 \%\end{array}$ & 3 & & \\
\hline $\begin{array}{l}\text { Downstream sediment } \\
\text { load same as upstream. }\end{array}$ & 0 & & \\
\hline
\end{tabular}

Method of evaluation:

Primary sources of information: Site environmental compliance data, permits. State or local water quality boards.

SCORE 


\section{B. PHYSICAL DISTURBANCE FROM WASTE DISPOSAL OPERATIONS}

1. Disposal of drill cuttings: Drill cuttings, generally consisting of small fragments of rock and soil that are removed from the well bore by the drill bit, are often disposed of on site. If the associated drilling muds are separated from the cuttings for recycling, disposal of cuttings represents a physical disturbance.

a. Total volume and/or area of drill cuttings:

Action: Estimate the total volume of drill cuttings or the total area covered by drill cuttings.

\begin{tabular}{||l|c|c|c|}
\hline \hline EVALUATION FACTORS FOR VOLUME OR AREA OF DRILL CUTTINGS \\
\hline EVALUATION FACTOR & $\begin{array}{c}\text { SCORING } \\
\text { GUIDELINE }\end{array}$ & COMMENTS & $\begin{array}{c}\text { UNCERTAINTY } \\
\text { (H, M, L) }\end{array}$ \\
\hline $\begin{array}{c}\text { Volume of cuttings }>500 \mathrm{~m}^{3} \\
\text { OR } \\
\text { Area of cuttings }>5 \text { ha }\end{array}$ & 5 & & \\
\hline $\begin{array}{c}\text { Volume of cuttings } 100 \text { to } 500 \mathrm{~m}^{3} \\
\text { OR } \\
\text { Area of cuttings } 1 \text { to } 5 \text { ha }\end{array}$ & 3 & & \\
\hline $\begin{array}{l}\text { Volume of cuttings }<100 \mathrm{~m}^{3} \\
\text { OR } \\
\text { Area of cuttings }<2 \text { ha }\end{array}$ & 1 & & \\
\hline
\end{tabular}

Method of evaluation:

Primary sources of information:

SCORE 
b. Change in drainage patterns:

Action: Determine whether drainage patterns on- or off-site have been altered by the accumulation of cuttings piles.

\section{EVALUATION FACTORS FOR ALTEREDI DRAINAGE PATTERNS FROM CUTTINGS} DISPOSAL

\begin{tabular}{|c|c|c|c|}
\hline $\begin{array}{l}\text { EVALUATION } \\
\text { FACTOR } \\
\end{array}$ & $\begin{array}{l}\text { SCORING } \\
\text { GUIDELINE }\end{array}$ & COMMENTS & $\begin{array}{c}\text { UNCERTAINTY } \\
(\mathrm{H}, \mathrm{M}, \mathrm{L})\end{array}$ \\
\hline $\begin{array}{l}\text { Drainage patterns } \\
\text { altered }\end{array}$ & 5 & & \\
\hline $\begin{array}{l}\text { Drainage patterns } \\
\text { may be altered }\end{array}$ & 2 & & \\
\hline $\begin{array}{l}\text { Drainage patterns } \\
\text { not altered }\end{array}$ & 0 & & \\
\hline
\end{tabular}

Method of evaluation:

Primary sources of information: Aerial photos, maps.

SCORE 
2. Disposal of produced waters: Produced water or brines that are generated along with the crude oil must be separated from the oil. Although produced water is often reinjected into the oil reservoir to increase the recovery of additional oil by helping to maintain reservoir pressure, produced water may also be disposed of in pits on site. These produced waters may contain toxic substances. However, the presence of standing waters or brines also pose a physical disturbance, which is assessed here...

a. Total surface area affected by disposal of produced waters:

Action: Estimate the total area where produced waters are or were present.

EVALUATION FACTORS TOTAL SURFACE AREA ON SITE THAT IS OR WAS USED FOR
DISPOSAL OR STORAGE OF PRODUCED WATERS
\begin{tabular}{|l|c|c|c||}
\hline $\begin{array}{l}\text { EVALUATION } \\
\text { FACTOR }\end{array}$ & $\begin{array}{c}\text { SCORING } \\
\text { GUIDELINE }\end{array}$ & COMMENTS & $\begin{array}{c}\text { UNCERTAINTY } \\
\text { (H, M, L) }\end{array}$ \\
\hline $\begin{array}{l}\text { Area contaminated } \\
>10 \text { ha }\end{array}$ & 6 & & \\
\hline $\begin{array}{l}\text { Area contaminated } \\
2 \text { to } 10 \text { ha }\end{array}$ & 3 & & \\
\hline $\begin{array}{l}\text { Area contaminated } \\
<2 \text { ha }\end{array}$ & 1 & & \\
\hline
\end{tabular}

Method of evaluation: Determine the total area that is or was at one time used for the disposal or storage of produced waters.

Primary sources of information: Site operational records, surveys, aerial photos.

SCORE 


\section{b. Total volume:}

Action: Estimate the total volume of produced waters remaining in surface containment structures on the site.

\begin{tabular}{|l|c|c|c||}
\hline \hline \multicolumn{2}{||}{ EVALUATION FACTORS FOR VOLUME OF PRODUCED WATERS REMAINING ON SITE } \\
\hline $\begin{array}{l}\text { EVALUATION } \\
\text { FACTOR }\end{array}$ & $\begin{array}{c}\text { SCORING } \\
\text { GUIDELINE }\end{array}$ & $\begin{array}{c}\text { COMMENTS } \\
\text { (H, M, L) }\end{array}$ \\
\hline $\begin{array}{l}\text { Produced water } \\
\text { volume }>1000 \mathrm{~m}^{3}\end{array}$ & 5 & & \\
\hline $\begin{array}{l}\text { Produced water } \\
\text { volume } 100 \text { to } \\
1000 \mathrm{~m}^{3}\end{array}$ & 3 & \\
\hline $\begin{array}{l}\text { Produced water } \\
\text { volume }<100 \mathrm{~m}^{3}\end{array}$ & 1 & & \\
\hline
\end{tabular}

Method of evaluation:

Primary sources of information:

SCORE 


\section{PHYSICAL DISTURBANCE FROM OIL SPILLS}

1. Spills of crude oil: In addition to toxic component, oil spills can create a physical barrier to plants and animals.

Action: Estimate total area covered by oil spills on site.

EVALUATION FACTORS FOR TOTAL SITE AREA COVERED BY SPILLS OF CRUDE OIL OR SLUDGE

\begin{tabular}{|c|c|c|c|}
\hline $\begin{array}{l}\text { EVALUATION } \\
\text { FACTOR }\end{array}$ & $\begin{array}{l}\text { SCORING } \\
\text { GUIDELINE }\end{array}$ & COMMENTS & $\begin{array}{c}\text { UNCERTAINTY } \\
(\mathrm{H}, \mathrm{M}, \mathrm{L})\end{array}$ \\
\hline $\begin{array}{l}\text { Total spill area } \\
>500 \mathrm{~m}^{3}\end{array}$ & 7 & & \\
\hline $\begin{array}{l}\text { Total spill area } \\
100-500 \mathrm{~m}^{3}\end{array}$ & 3 & & \\
\hline $\begin{array}{l}\text { Total spill area } \\
<100 \mathrm{~m}^{3}\end{array}$ & 1 & & \\
\hline
\end{tabular}

Method of evaluation: Determine the total site area that has been affected by oil spills throughout the operational history of the site.

Primary sources of information: Site records.

SCORE 


\subsection{Summary of scoring guidelines for assessing relative need for remediation.} CHARACTERISTIC

\section{SCORING MAXIMUM GUIDELINE SCORE}

CONTAMINANT CHARACTERISTICS
A. Degree of hazard

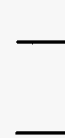
B. Contaminant quantity
-
C. Physical state of contaminants
D. Special considerations

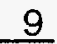
6

\section{EXPOSURE PATHWAYS}

A. Groundwater

1. Contamination beyond property boundary

2. Potential for groundwater contamination

a. Engineered subsurface containment

b. Thickness of confining layer over aquifer

c. Hydraulic conductivity of confining layer

d. Annual rainfall

e. Hydraulic conductivity of aquifer(s) of concern

3. Special Considerations

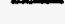

B. Surface Water

1. Contamination of water/effluent from the site

2. Potential for surface water contamination
a. Surface containment
b. Distance to perennial surface water
c. Topography
d. Run-off potential
e. Flood potential

3. Special considerations

C. Direct Contact

1. Known contamination of media off-site:

2. Potential for direct human and/or animal contact
a. Airborne emissions (gases, vapors, dust, etc.)
b. Accessibility of site
c. Hazardous soil gas migration

3. Special considerations 


\section{RECEPTORS}

A. Human and Animal Uses:

1. Adverse impact on humans or domestic animals

2. Potential for impact on humans or animals

a. Drinking water supply

i. Known impact on drinking water supply

ii. Potential for impact on drinking water supply

- Proximity to drinking water supply

- Availability of alternate drinking water supply

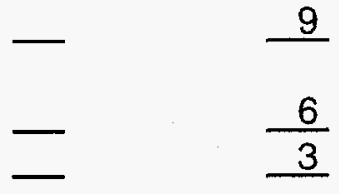

b. Other water resources

i. Known impact on used water resource

ii. Potential for impact on water resources

- Proximity to water resources activities

- Use of water resources

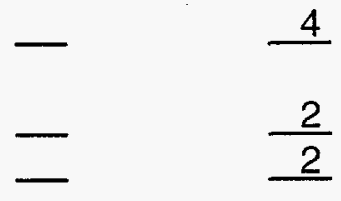

c. Direct human exposure

i. Known contamination of land used by humans

ii. Potential human exposure through land use

3. Special considerations

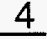

B. Environment

1. Known adverse impact on a sensitive environment

2. Potential for impact on sensitive environments

a. Distance to nearest sensitive environment

b. Distance to groundwater resource(s)

$\frac{10}{6}$

\section{PHYSICAL DISTURBANCE}

A. Physical disturbance from operations and infrastructure

1. Disturbance associated with E\&P infrastructure

2. Removal of vegetation and/or soil

a. Total area of disturbed vegetation and soil

b. Depth of soil disturbance

c. Critical habitat

d. Presence of exotic invader species

3. Sedimentation of streams

B. Physical disturbance from waste disposal operations

1. Disposal of drill cutting

a. Total volume and/or area of drill cuttings

b. Change in drainage patterns

10

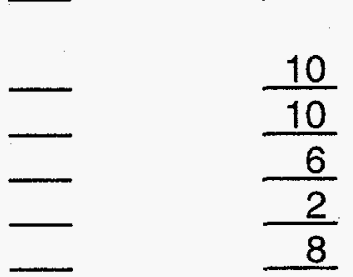

2. Disposal of produced waters

a. Surface area affected by disposal of produced waters

b. Total volume of produced waters

C. Physical disturbance from crude oil spills

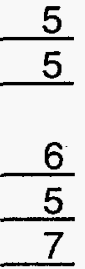

TOTAL 


\subsection{REFERENCES}

ASTM. 1995. Standard Guide for Risk-Bas;ed Corrective Action Applied at Petroleum Release Sites. American Society of Testing and Measurements. Designation E 1739-95. Philadelphia, Pennsylvania.

CCME. 1992. National Classification System for Contaminated Sites. Report CCME EPCCS39E.

Carls, E.G., D.B. Fenn, and S. Chaffey. 19:95. Soil contamination by oil and gas drilling and production operations in Padre Island National Seashore, Texas, U.S.A. Journal of Environmental Management 45:273-286.

Chilingarian, G.V. and P. Vorabutr. 1981. Drilling and Drilling Fluids. Elsevier Scientific, Amsterdam.

Gettleson, D.A. 1980. Effects of oil and gas drilling operations on the marine environment. In: R.A. Geyer (ed.) Marine Environmental Pollution. I. Hydrocarbons. Elsevier Scientific, Amsterdam. pp. 371-411.

Kanz, J.E. and M.J. Cravey. 1987. Oil well drilling fluids: Their physical and chemical properties and biological impact. In: J. Saxena (ed.), Hazard Assessment of Chemicals, vol. 5. Elsevier Scientific, Amsterdam. pp. 37-106.

McDonald, T.J., J.M. Brooks, and M.C. Kennicutt II. 1984. Release of volatile liquid hydrocarbons from spilled petroleum. Bulletin of Environmental Contamination and Toxicology 32:621628.

Monaghan, P.H., C.D. McAuliffe, and F.T. Weiss. 1980. Environmental aspects of drilling muds and cuttings from oil and gas operations in offshore and coastal waters. In: R.A. Geyer (ed.), Marine Environmental Pollution. I. Hydrocarbons. Elsevier Scientific, Amsterdam.

Neff, J.M. 1982. Fate and biological effects; of oil well drilling fluids in the marine environment: $A$ literature review. EPA-600/3-82-064.

Rope, R.C. and R.P. Breckenridge. 1993. U.S. Fish and Wildlife Service Lands Biomonitoring Operations Manual. Idaho National Engineering Laboratory report EGG-EST-9222.

Sullivan, B. and S. Johnson. 1993. "Oil" you need to know about crude. Soils 8, May 1993, 8-13.

U.S. Environmental Protection Agency. 19ऽ12. Framework for ecological risk assessment. Washington DC: Risk Assessment Forum, U.S. Environmental Protection Agency. EPA/630/R-92/001.

USEPA. 1996. Proposed guidelines for ecological risk assessment. U.S. Environmental Protection Agency Document EPA/630/R-95/002B, August, 1996. 